\title{
Resimli öykü kitaplarını değerlendirme ölçeğinin geliştirilmesi: Geçerlik ve güvenirlik çalı̧̧ması*
}

\section{Reliability and validity of the Picture Story Assessment Scale}

\section{Makale Geçmişi \\ Geliş : 20 Ocak 2020 \\ Düzeltme : 4 Temmuz 2020 \\ Kabul : 29 Eylül 2020}

\section{Makale Türü}

Arastirma Makalesi

\section{Article History}

Received : 20 January 2020

Revised : 4 July 2020

Accepted : 29 September 2020

\section{Article Type}

Research Article

\author{
Ayşegül Deniz' ${ }^{1}$ Mübeccel Sara Gönen ${ }^{2}$
}

Öz: Bu çalışmada resimli öykü kitaplarının niteliğini belirlemek için bir ölçme aracının geliştirilmesi amaçlanmıştır. Resimli öykü kitaplarında bulunması gereken resimleme ve içerik ile ilgili özellikler alanyazın incelenerek belirlenmiş ve ölçek maddeleri oluşturulmuştur. Kapsam geçerliliği için 7 uzmanın görüşlerine başvurulmuştur. Ölçek üçlü likert tipinde geliştirilmiş olup yeterli (3), kısmen yeterli (2), yetersiz (1) şeklinde derecelendirilmiştir. Ölçeğin geçerlik güvenirlik çalışması tesadüfi örnekleme yöntemiyle seçilen 200 resimli öykü kitabı ile gerçekleştirilmiştir. Yapılan analizler sonucunda KMO değeri .92 olarak bulunmuştur. Faktör analizi sonuçları içerik ve resimleme özellikleri ile ilgili 21 maddeden oluşan ölçeğin tek boyutlu olarak değerlendirilebileceği biçiminde yorumlanmış ve ölçeğin toplam varyansın \%48.927'sini açıkladığı belirlenmiştir. Ölçeğin Cronbach Alfa katsayısı .94 olarak hesaplanmıştır. Puanlayıcı güvenirliği için iki puanlayıcı arasındaki korelasyon katsayısı .92 olarak bulunmuştur. Geçerlik ve güvenirlik çalışmalarının sonuçları ölçeğin kullanılabilir olduğunu göstermektedir. Geliştirilen ölçeğin araştırmacılar, öğretmenler, ebeveynler, kütüphaneciler, çocuk gelişimi uzmanları, yayıncılar, yazarlar ve çizerler tarafından kullanılabileceği düşünülmektedir.

Anahtar Kelimeler: Resimli öykü kitapları, Çocuk edebiyatı, Okul öncesi eğitim, Geçerlik, Güvenirlik

Abstract: This study aims to develop a measurement tool to determine the quality of picture story books. The scale items were engendered by examining the related literature and the features related to the illustrations and contents that should be found in the picture story books. Views of 7 field specialists were taken for content validity. The scale is a 3-point Likert-type scale and the response codes to be given to each item range from good (3), fair (2), poor (1). The validity and reliability study of the scale was carried out with 200 picture story books selected by a random sampling method. KMO value of the scale was found to be .92 . The results of the factor analysis were interpreted that the scale consisting of 21 items could be evaluated as one-dimensional and the scale explained $48.927 \%$ of the total variance. The Cronbach's alpha coefficient of the scale was calculated as .94. The correlation coefficient between the two raters was calculated as .92 . The results of reliability and validity indicate that the scale is usable for assessing picture story books' quality. The scale is thought to be used by researchers, teachers, parents, librarians, child development specialists, publishers, authors, and illustrators.

Keywords: Picture story books, Children's literature, Preschool education, Validity, Reliability

\footnotetext{
*Bu çalışma, birinci yazarın ikinci yazar danışmanlı̆ında tamamlamış olduğu "Resimli Öykü Kitaplarının ve Kitap Okuma Etkinliklerinin Niteliğinin Beş Yaş Çocuklarının Dil Gelişimiyle İlişkisininin İncelenmesi” başlıklı doktora tez çalışmasından üretilmiştir ve 6. Uluslararası Okul Öncesi Eğitim Kongresinde "sözlü bildiri" olarak sunulmuştur. 


\section{SUMMARY}

\section{Introduction}

Children's literature plays an important role in children's learning and lives. The young child can develop socially, personally, intellectually, culturally, and aesthetically through experiences with picture books. Books enable the newly socialized child to explore interpersonal relationships and human motives. Picture books communicate self-acceptance, and they model coping strategies for children who are just learning to deal with powerful emotions. Through picture books, children meet families, settings, and cultures that are in some ways similar and in some ways different from their own. As a result, picture books contribute to the child’s cultural identity and multicultural awareness (Jalongo, 2004).

Qualified books enable children to have information about the experiences to establish a connection between their own lives and to develop their coping skills for different situations (Gönen \& Veziroğlu, 2013). Children who develop their knowledge and experiences through books develop their personality and learn to look at life from different perspectives (Işıtan \& Gönen, 2006). Acquiring reading habit is the main target of children's literature and picture story books have an important role to achieve this goal.

Children from an early age need to encounter with qualified books, both at home and school. Books, which have a very important role in the development of children, have certain characteristics that they should carry in terms of language and illustration features.

It is observed that the number of picture story books prepared for preschool children has increased in recent years. Although this is a positive development for children to access more books meet with many different books, it is seen that there is an increase in the number of books that are not suitable for child development and only for commercial purposes. Picture story books are very important to support children's development and education. However, it is seen in the literature that there is no valid and reliable measurement tool for picture story boks. This study is considered to be important in terms of determining whether the picture story books have the characteristics they should have and evaluating the quality of them.

\section{Method}

The aim of this study is to develop a measurement tool to determine the quality of picture story books. The validity and reliability study of the scale was carried out with 200 picture story books published between 2006 and 2016 selected by a random sampling method. The scale items were engendered by examining the related literature and the features related to the illustrations and contents that should be found in the picture story books were determined. 8 of these items were prepared for illustration features and 15 for content features. In the items related to illustration features that should be taken into consideration in the book's drawing, such as the cover picture and the pictures and color features in the inner pages of the book, the suitability of the pictures for the development of children, the relationship between text and pictures, and 
more than half of the page are pictures. As for the content features, the items were determined in terms of the language, theme, plot, style, and characters of the story in terms of the suitability of the development and needs of the children. All items in the scale were positively expressed. Views of 7 field specialists were taken for content validity. The scale is a 3-point Likert-type scale and the response codes to be given to each item range from good (3), fair (2), poor (1) quality.

\section{Results}

At the converted basic components' analysis performed for the factorability in the study is the KMO (Kaiser-Mayer-Olkin) value determined to be .92, and the result of the Barlett's test as 3183.840. The results of the factor analysis were interpreted that the scale consisting of 21 items ( 7 items illustration and 14 items content features) could be evaluated as one-dimensional and the scale explained $48.927 \%$ of the total variance and the factor loads vary between .414-.869. According to the results of the item total correlation analysis, expected to be greater than .25 (Kayış, 2009, s. 412) are the item total correlation coefficients varying between .37 and .83 and the item residual correlation coefficients are statistically meaningful. The Cronbach's alpha coefficient of the scale was calculated as .94. The correlation coefficient between the two raters was calculated as .92. The lowest score that can be obtained from the scale is 21 , while the highest score is 63 . While the low scores obtained from the scale indicate that the quality of the story book was insufficient, higher scores indicate much higher quality.

\section{Conclusion and Discussion}

It is by the end of all analysis seen that the Picture Story Books Assessment Scale is a valid and reliable usable measurement tool at determining the quality of picture story books. There is no scale study regarding the measurement of the picture story books' quality and it is thought that the developed scale might eliminate this deficit and contribute to the literature. The scale is thought to be used by researchers, teachers, parents, librarians, child development specialists, publishers, authors, and illustrators. 


\section{GİRIŞ}

Çocuk edebiyatı kavramı, 20. yüzyılın ilk çeyreğinde ortaya çıkmış ve "Hedef kittle olarak doğrudan çocuğu ele alan bir duyarlke ve cocuklarm düreyine uygun anlatım biçimi ile onlara seslenen edebiyat" anlaminda kullanılmaya başlanmıştır (Karatay, 2011, s. 99). Çocuk edebiyatı "2-14 yaşlar arasındaki kimselerin ibtiyacm karşslayan bir edebiyat alani" olarak (Oğuzkan, 2013, s. 3) ve "Cocuklarn duygu ve düs̆̈̈nce dünyalarm sanatsal nitelï̈i olan dilsel ve görsel iletilerle zenginlestiren ürünlerin genel adı" olarak tanımlanmaktadır (Sever, 2008, s. 17). Mallan (2017), çocuk edebiyatını okuyucularına zevk, düşünme ve duygusal katılım için birçok yol sunan, kendi başına dinamik bir varlık olarak yorumlamaktadır. Gönen (2013), çocukların zevkle okuduğu bunun yanı sıra ruhsal ve eğitsel ihtiyaçlarını da karşılayan, çocukların gelişim özellikleri dikkate alınarak hazırlanan, ders ve oyun kitapları dışında yer alan edebiyat ürünlerinin çocuk edebiyatı kapsamında değerlendirilebileceğini belirtmektedir.

Çocuk edebiyatı, çocukların öğrenmelerinde ve yaşamlarında önemli bir rol oynamaktadır. Okul öncesi dönem çocuklarına yönelik yazılmış çocuk edebiyatı ürünleri arasında en önemlilerinden biri resimli öykü kitaplarıdır. Bu kitaplar "O-6 yas arası çocuklarn gelişimine katkıda bulunmak, okuma alışkanlĭgr kazandırmak için büyük resimli ve az yaz̨l hažrlanmıs kitaplar" olarak tanımlanmaktadır (Uzuner-Yurt, 2012, s. 75). Resimli öykü kitapları, okuyucuların ilgisini çekerek okumaya odaklanmalarını sağlayan kısa metinli bir anlatı yapısına ve bir dizi görsele sahip olan kitaplar olarak adlandırılmaktadır (Dockett, Perry ve Whitton, 2006). Çocuklar için önceleri bir oyuncak olan kitap, daha sonra içindeki yazılı masalları dinlemekten, tekerlemeleri yinelemekten hoşlandığı, sayfalarındaki resimlerden yola çıkarak öyküyü tamamladığ1 ve yaratıcıllı̆ını geliştirdiği bir eğlence arac1 haline gelmektedir (Stebler, 2012).

Çocukların ilk kitapları çocuğun çevresindeki insan, hayvan ve eşyaların yer aldığı ABC kitaplarıdır. Bu kitapların resimleri sade, gerçekçi ve parlak renklidir. Dört-beş yaş grubundaki çocuklar için hazırlanan kitaplarda, resimlemeler ön planda olup kısa metinler yer almaktadır. Altı-yedi yaş grubuna yönelik resimli öykü kitaplarında dil ve kavram yönünden daha gelişmiş ve detaylı metinler bulunmaktadır (Gönen, 2013). Çocukların yaşları ilerledikçe dikkat süreleri uzadığından daha küçük yaştaki çocuklar için bir formalık (16 sayfa) kitaplar okunması gerekirken, 5 yaş ve sonrasında çocuklar için iki formalık (32 sayfa) ve daha kalın resimli öykü kitapları okunabileceği belirtilmektedir (Ural, 2013).

Resimli kitaplar çocukların duygusal zekâ, yaratıcılık, kişilik ve sosyal becerilerinin gelişimi açısından önem taşımaktadır. Resimli öykü kitapları yoluyla çocukların entelektüel, kültürel ve estetik gelişimleri desteklenmektedir. Resimli kitaplar çocuğun kültürel kimliğine ve çok kültürlü 
farkındalığına katkıda bulunmaktadır (Jalongo, 2004; Norton ve Norton, 2010). Bunların yanı sıra nitelikli çocuk edebiyatı eserleri, çocukların eserlerde yer verilen yaşantılarla ilgili bilgi sahibi olmalarını, kendi yaşamları arasında bağlantı kurmalarını ve farklı durumlara yönelik baş etme becerilerini geliştirmelerini sağlamaktadır (Gönen ve Veziroğlu, 2013). Bilgi ve deneyimlerini kitaplar aracılığıyla geliştiren çocukların kişilikleri gelişmekte ve çocuklar hayata farklı açılardan bakmayı öğrenmektedir (Işıtan ve Gönen, 2006). Kitaplar, birbirinden farklı öyküler aracıllı̆ıyla çocuklara eğlenme ve deneyim elde etme fırsatını verirken; bir öykünün, gerçeğin tek ve olası versiyonu olmadığı konusunda da eleştirel bir bakış açısı sunmaktadır (Nodelman ve Reimer, 2003). Kitaplar, çocuk edebiyatının en temel amacı olan kitap sevgisi ve kitap okuma alışkanlığ1 kazandırmada da önem taşımaktadır (Sever, 2008).

Çocuklar okumayı bilmeden önce kendilerine okunan kitaplardan yeni bilgiler öğrenmektedir. Kitaplara bakmak ve kitapları dinlemek çocukların dünyayı anlamlandırmalarına ve dil gelişimlerinin desteklenmesine yardımcı olmaktadır (Horst ve Price, 2015). Okul öncesi dönemde çocuklara kitap okumanın dil ve erken okuryazarlık becerilerinin gelişiminde de etkili olduğu yapılan araştırmalarda ortaya koyulmuştur (Blewitt, Rump, Shealy ve Cook, 2009; Justice, Pullen ve Pence, 2008; Mol, Bus, De Jong ve Smeets, 2008). Çocuklara kitap okumak onların okuryazar olmalarına temel olan bilgi ve stratejileri geliştirmelerini sağlamaktadır (Teale, 2003).

Çocuklara yönelik öykü kitaplarında kullanılan dil yapıları ve sözcük çeşitliliği, günlük konuşma diline göre daha kompleks ve sofistike olduğundan resimli kitapların metni, küçük çocuklar için önemli bir sözcük kaynağı olarak değerlendirilmektedir (Cameron-Faulkner ve Noble, 2013; CrainThoreson, Dahlin ve Powell, 2001; Hayes ve Ahrens, 1988; Montag, Jones ve Smith, 2015). Sözcük bilgisinin ve dinlediğini anlama becerilerinin desteklenmesinde iyi öykü kitapları önemli rol oynamaktadır (McGee ve Schickedanz, 2007).

Yapılan araştırmalar ebeveynlerin ve öğretmenlerin çocuklarına en fazla okudukları kitap türünün resimli öykü kitaplar olduğunu göstermektedir (Clark ve Foster, 2005; Price, van Kleeck ve Huberty, 2009; Robertson ve Reese, 2017). Ancak ebeveynler çocuklarına daha kompleks içeriğe sahip olan nitelikli resimli öykü kitaplarını okuduklarında, kitap hakkında daha fazla konuşmakta ve bu konuşmalar dil açısından daha zengin olmaktadır (Muhinyi, Hesketh, Stewart ve Rowland, 2020). Resimli öykü kitaplarındaki metinlerin çocukların öğrenmelerini ve hayal güçlerini geliştirecek ilginç fikirler sunması gerekmektedir. Çocuklara yazılı dili kullanma ve kendi öykülerini oluşturma olasılıklarını göstermek açısından öykülerin iyi yazılmış olması oldukça önem taşımaktadır (Stagg Peterson ve Swartz, 2008). 
Okul öncesi dönemde çocukların konuşma becerilerini geliştirmek ve kitaplara dair yorumlamalar yapabilmeleri için öğretmenlerin de çocuk kitapları konusunda bilgili olmaları ve çocuk kitaplarını planlı bir şekilde kullanmaları gerekmektedir (Sipe, 2008). Nitelikli çocuk edebiyatı ürünleri çocuklara okuma stratejileri açısından temel oluştururken, kendi hayatlarıyla bağlantı kurmanın yollarını da sunmaktadır. Öğretmenler farklı konular hakkında kitaplar okuyarak çocukların yeni bilgiler edinmelerini sağlayabilmektedir. Buna ek olarak sınıflarında çevreyi ve toplumu çeşitli şekillerde etkileyen öğrenme firsatlarını da kitaplar aracıllğıyla yaratabilmektedir (Wiseman, 2011). Çocuklar, kitap okuma etkinliklerinde nitelikli kitaplar aracılı̆̆ıyla yapılan tartışmalarda, öğretmen desteğiyle kompleks anlamlar oluşturmaktadır (Hoffman, 2011). Fakat kısa ve basit kitaplar, daha ayrıntılı olay örgüsü içeren öykü kitapları kadar tartışmaya teşvik edici olmamaktadır (Dickinson ve Keebler, 1989). Bu nedenle çocuklara okunacak kitapların, çocuklar açısından ilgi çekici karakterler ve çizimler içeren; yetişkine akıcı ve etkileyici bir okuma yapmak için fırsat sunma özelliklerini taşıması gerekmektedir (Lane ve Wright, 2007).

Wagner (2017) kitap seçiminin kültürel açıdan dikkate değer olma, çocukların deneyimlerini yansıtma, karakterin cinsiyeti, öykünün dil özellikleri ve bilişsel gelişimi destekleme açısından kompleks olması, güçlü bir öyküye sahip olması gibi özellikler kapsamında yapılmasının gerektiğini belirtmektedir. Kitapların, çocukların düşünme becerilerini geliştirme, farklı kültürlere sayg1lı olma ve korkutucu öğelere yer vermeme gibi kriterleri karşılamaları da gerekmektedir (Mac Naughton ve Williams, 2009). Çocuklara okumak için seçilecek kitaplarda aşağıdaki öğelerin göz önünde bulundurulması önerilmektedir (Cramer 2004; Hancock, 2007; Russell, 2014; Temple, Martinez ve Yokota, 2006):

- Çocukların yaş düzeyi, ilgileri, duygusal, sosyal, bilişsel ve dil gelişimleri dikkate alınmalıdır.

- Kitap anlamlı bir temaya, tartışmak için yeterli bir derinliğe, hatırlanabilir bir dile ve çocukların yaşantılarına uygun karakterlere sahip olma kriterlerini karşılamalıdır.

- Ticari amaçla yazılmıs kitaplardan öte zengin bir dil içeriğine sahip, resimleri çocukların estetik zevklerine hitap eden kitaplar seçilmelidir.

- Öykünün içeriği ve resimlemeler etnik, dil, din, etnik köken, cinsiyet vb. açısından kalıp yargılar oluşturmamalıdır.

Yazılı eserlerden zevk almak ve yazılı eserleri anlamak doğuştan gelen beceriler olarak değerlendirilmemektedir. Çocuklar, nitelikli eserler ile etkileşime girerek bu becerilerle ilgili stratejileri inşa etmektedir (Neuman ve Roskos, 2007). Resimli öykü kitapları, çocukların kişisel yaşamlarını geliştirmelerinin yanı sıra onları gelişimsel ve eğitimsel olarak da destekleyen araçlardır. 
Çocukların küçük yaşlardan itibaren hem ev hem de okul ortamlarında nitelikli eserle karşılaşmaları gerekmektedir (Gönen ve Veziroğlu, 2013). Bu nedenle resimli öykü kitaplarının nitelik açısından taşıması gereken özellikler bulunmaktadır.

\section{Resimli Öykü Kitaplarında Bulunması Gereken Özellikler}

Resimli öykü kitaplarında bulunması gereken özellikler biçimsel özellikler, içerik özellikleri ve resimleme özellikleri başliklarında incelenmektedir.

\section{Biçimsel Özellikler}

Büyüklük (Boyut). Resimli öykü kitapları biçim ve boyut açısından çeşitlilik göstermektedir. Biçim açısından yatay ve dikey biçiminde olan kitaplar bulunmaktadır. Kimi kitaplar çocuğun kendi elleriyle kolayca tutabileceği boyuttayken $(15 \times 15 \mathrm{~cm})$; kimisi yetişkinin çocuğa kitap okurken önlerine açabileceği kucak boyu $(24 \times 30 \mathrm{~cm})$ olarak adlandırllan boyutta olabilmektedir (Ural, 2013). Çocukların sürekli değişen ilgilerini kitaplara yöneltebilmek için erken çocukluk döneminde farklı boyutlardaki kitaplardan yararlanılması önerilmektedir. Çocuklar değişik büyüklükteki kitapları incelemekten ve okumaktan zevk almaktadır. Kitapların değişen boyutları hacim ve ağırlık yönünden çocukların taşıyabileceği ve çocukların el yapısına uygun şekilde olması gerekmektedir (Oğuzkan, 2013; Sever, 2013).

Kâğıt. Çocuk kitaplarında kullanılan kâğıdın dayanıklı (1. veya 2. Hamur olmalı) ve mat olması, 1şığı yansıtıp gözü yorduğu için kuşe kâğıt kullanımından kaçınılması önerilmektedir (Yılar ve Celepoğlu, 2013). Kitaplarda kullanılan kâğıdın resimlerin ve yazıların arkaya geçirecek incelikte olmaması, resimlerin niteliğini ve renkleri yansıtabilme ve yazıların da kolay bir şekilde okunmasına olanak sağlama özelliklerini taşıması gerekmektedir (Sever, 2013; Ural, 2013).

Kapak. Öykü kitaplarının ön kapağında öykünün içeriğini yansıtır nitelikte öykünün ismi ve kapak resmi yer almaktadır. Kitabın ismi ve kapakta yer alan resimlemeler kitabın konusu ile ilgili fikir edinilmesini sağlamaktadır (Lynch-Brown, Tomlinson ve Short, 2011). Kitabın kapağında yer alan renk, resim ve yazı gibi öğeler çocukların dikkatini kitaba çeken ilk özellikler olduğu için kapak tasarımının; ilgi çekici olma, öykünün konusu ve öyküde yer alan karakterler ile ilgili çocuğa ipuçları verme ve çocukların ön bilgilerini harekete geçirici olma gibi özelliklere sahip olması gerekmektedir (Karatay, 2011). Ayrıca kitabın kapağının dayanıklı olması açısından kalın karton olması önerilmektedir.

Sayfa düzenlemesi. Resimlerin ve metnin sayfaya nasıl yerleştirileceği sayfa düzenlemesi kapsamında değerlendirilmekte olup oldukça önem taşımaktadır. Metinler, her sayfada aynı yerde olabileceği gibi bazı sayfalarda sağ tarafta, bazı sayfalarda sol tarafta ya da sayfaların farklı yerlerinde 
olabilmektedir (Hancock, 2007). Kitapların sayfa düzenlemesi yapıllırken resimlerin yerleştirilmesinde akıcılığın desteklemesine dikkat edilmesi gerekmektedir. Resimler daha çok metnin üzerinde, kenarında ya da sol tarafta bir sayfa olarak yer alabilmektedir (Güleryüz, 2003).

Ciltleme. Kitabın ciltlemesi dayanıklıllğı etkilediği için oldukça önem taşımaktadır. Çocuk kitaplarının iyi bir şekilde ciltlenmesi çocukların kitapları uzun süre kullanabilmelerini sağlamaktadır. İyi bir ciltlemenin yanı sıra kitabın cildinin kolay açılabilmesi ve okunabilmesi gerekmektedir. Kitapların ciltlenmesi üç türlü yapılabilmektedir. Bunlardan ilki ince tel ya da iplikle dikilmesi; ikincisi tel zımba ile dikilmesi, üçüncüsü yapıştırma tekniğiyle sayfaların bir araya getirilerek ciltlenmesidir. İplikle dikiş tekniği maliyetli olmasına rağmen dayanıklılık ve kullanışl1lık açısından yapıştırma tekniğinden sonra en iyisi olarak değerlendirilmektedir. Ülkemizde en ekonomik ciltleme tekniği olarak kitapların tel zımbayla dikildiği görülmektedir. Kitaplar ortadan bir tel zımba ile dikildiklerinde çok kolay dağılabildiklerinden, tel zımbanın kullanılması durumunda birden çok tel zımba ile dikilmesine dikkat edilmesi gerekmektedir (Karatay, 2011; Ural, 2013).

Punto. Okul öncesi dönem çocukları için hazırlanan kitapların yazılarında 24, 22 ya da 20 punto büyüklügünün kullanılması gerekmekte; diğer öğretim kademelerinde ise çocukların yaşları büyüdükçe harflerin boyutlarının küçülmesi gerekmektedir. Okumaya yeni başlayan çocuklar için 16-18 punto büyüklüğünün kullanılması önerilmektedir (Sever, 2013; Ural, 2013).

\section{İçerik Özellikleri}

Tema. Yazarın eserinde yer verdiği temel düşünceye, ana yönelim tema olarak tanımlanmaktadır. Öykü ne anlama geliyor, öyküyü birbirine bağlayan büyük fikir nedir, öyküdeki ana karakterin hayatla ilgili ifade ettiği düşünceler nelerdir, öyküde hangi değerlere yer verilmektedir, öykünün mesajı nedir sorularının cevabı temayı anlatmaktadır (Cramer, 2004). Çocuklar için yazılan eserlerde temanın açık ve seçik bir şekilde olması gerekmektedir. Teması belirsiz veya değissik yorumlara açık eserler çocukları kararsızlıklara ve yanlış anlamalara götürebilmektedir. Bu nedenle yazarın ve çizerin çocuklara ne gibi düşünce ve görüşleri kazandırmak, onlarda hangi tavırları ve alışkanlıkları geliştirmek istediğini bilmesi önemli bir konu olarak değerlendirilmektedir (Oğuzkan, 2013).

Konu. Konu, kitabın temel kavramıdır ve çocuklara verilmek istenen mesajı, düşünceleri ya da değerleri kapsamaktadır (Işıtan, 2013). Okul öncesi dönemde çocuk kitaplarında ele alınacak konuların, çocukların bireysel ilgi ve ihtiyaçları doğrultusunda evrensel değerlere önem verilerek seçilmesi; metinde işlenen konunun, 2-7 yaş gelişim düzeyindeki çocuklar için açık ve anlaşılır olması gerekmektedir. Konuların, çocukların gerçek hayatlarından yola çıkılarak yakın çevrelerindeki olay ve olgular arasından seçilebileceği, mizah duygusu içerme, eğlendirici ve 
dinlendirici olma özelliklerini taşıyabileceği belirtilmektedir (Gönen, 2013; Karatay, 2011; Oğuzkan, 2013; Sever, 2008).

Çocukların yaşları büyüdükçe çocuk kitapları için seçilecek konu alanı da genişlemektedir. Çocuklar erken çocukluk döneminde somut düşünme becerilerine sahip olmakla birlikte zengin bir hayal gücüne de sahip olduklarından, çocukların hayal güçlerini harekete geçiren olağan üstü olaylar ve çocukların yaşamlarında karşılaşabilecekleri her olayın çocuk kitabı konusu olarak ele alınabileceği; önemli olanın konunun kendisinden öte konunun işleniş biçimi olduğu belirtilmektedir (Tür ve Turla, 1999).

Karakterler. Edebiyat yapıtlarında, yazar-okur etkileşiminin niteliğinin belirlenmesinde çocukların öykündükleri kahramanlar ve bu kahramanların özellikleri önem taşımaktadır. Öykünün ana karakteri olaylara yön veren kişi olduğu için çocuklar ana karakter ile özdeşim kurmayı istemektedir. $\mathrm{Bu}$ nedenle çocuklara yönelik eserlerde kahramanların özellikleri fiziksel ve ruhsal özellikler açısından abartısız ve inandırıcılık düzeyi yüksek olması gerekmektedir. Öyküdeki olaylara bağlı olarak ana karakterin değişen kişilik özellikleri, çocuğun insan gerçekliğine dair durumları anlamasına katkıda bulunmaktadır (Sever, 2008). Karakterler; tanımlamalar, eylemler, davranışlar ve öyküdeki diğer karakterlere verdikleri tepkiler yoluyla yaratılmakta; fiziksel olarak kendilerine has özellikleri taşıyabilmektedir. Öyküler, karakterler ve karakterlerin yaptıkları seçimler ile ilerlemektedir (Cramer, 2004).

Plan. Yazar tema, konu ve karakterler kapsamında duygularını, düşüncelerini ve farklı yaşantıları bir plan çerçevesinde sıralayarak anlatmaktadır (Cramer, 2004). İyi ve dikkatli bir şekilde hazırlanan bir plan sayesinde eserin ana fikri kolayca anlaşılabilmektedir. Başlangiç, düğüm ve sonuç evreleri birbirini doğal ve anlamlı bir şekilde takip ettiği zaman eserin okur üzerindeki etkisi artmaktadır. Çocukların gelişim özellikleri göz önüne alındığında planda kısa bir giriş bölümü ile heyecanlı ve ilgi çekici olayları kapsayan bir dügüm bölümünün olması gerekmektedir. Sonuç bölümünün çocukların ilgisini koruyacak şekilde, beklenmedik olayları içeren bir çözümle sonuçlanması önerilmektedir (Oğuzkan, 2013). Küçük yaştaki çocuklar günlük rutinleri içeren ve yakın çevreleri ile ilgili olayları ele alan öykülerden hoşlanmaktadır. Ancak 4 yaşından itibaren heyecan unsurunun da olmasını istemektedir. Bu nedenle öykünün planında çocuğun dikkatini çekecek nitelikte bir heyecan yaratmak için çatışmaya yer verilmesi gerekmektedir. Bu çatışma öyküdeki ana karakterin kendi içsel çatışması olabileceği gibi doğaya karşı ya da başka bir kişiye karşı olabilmektedir (LynchBrown, Tomlinson ve Short, 2011). Okul öncesi dönem çocukları için hazırlanan öykü kitaplarındaki kurguda, olayların mantıklı bir neden sonuç ilişkisi içinde gelişmesi gerekmektedir. Zamanın doğrusal olarak ilerlemesi önerilmekte; geri dönüşlere (flash back) yer verilmemesi ve 
olaylardaki çatışmaların düğüm noktasına ulaştıktan sonra hemen çözüme ulaştırılması gerekmektedir (Karatay, 2011).

Üslup. Üslubu, öyküde kullanılan dil ve sözcükler oluşturmaktadır. Cümle yapısı, seçilen sözcükler arasındaki anlam ve ses ilişkileri, kullanılan deyimlerin hepsi bir üslubu diğerinden ayıran unsurlar olarak karşımıza çıkmaktadır. Çocuklara yönelik yazılmış öykü kitaplarında kullanılan üslup ve dil oldukça önem taşımaktadır. Yapmacık, zevksiz, bayağı ve çocuklara uygun olmayan bir anlatım biçiminden, eski ve anlaşılması güç sözcük kullanımından kaçınılması gerekmektedir (Oğuzkan, 2013). Yazarın üslubu, edebi eserin türüne ait özellikler, yazarın dünya görüşü, yaşam biçimi ve yetiştiği çevre gibi etmenler tarafindan belirlenmektedir. Yazarlar üslup olarak şiirsel bir dil ya da masal dilini kullanmayı tercih edebilmektedir. Bazı öyküler kahramanın ağzından, bazı öyküler de yazarın kendi ağzından anlatılmaktadır. Bu farklılaşmalar her yazarın kendine özgü bir üsluba ve anlatım biçimine sahip olmasından kaynaklanmaktadır (Karatay, 2011).

Dil. Resimli öykü kitaplarında açık ve anlaşılır bir dil kullanılması, somut sözcüklere soyut sözcüklerden daha çok yer verilmesi, yazım ve noktalama kurallarına dikkat edilmesi, yabancı sözcükler yerine Türkçe sözcüklerin kullanılması önerilmektedir. Çocuğun seviyesinin üzerinde kavramakta zorlanacağı uzun cümleler ve seviyesinin altında olan kısa ve basit cümleler kitaba karşı olan ilgisini azaltacağı için cümle uzunluklarında gelişim özelliklerinin dikkate alınması önem arz etmektedir (Karatay, 2011). Bunların yanı sıra çocuklar açısından kompleks anlam ve imgelem geliştiren sözcükler ve ifadeler içeren zengin bir dil kullanılması; anlamı bilinmeyen yeni sözcüklere ya da anlamı bilinen sözcüklerin farklı anlamlarda kullanımlarına yer verilmesi gerekmektedir. Zengin bir dil ile süslü ya da uzun cümleler kullanılmasından ziyade yazarın orijinal, sanatsal ve iyi yapılandırılmış bir metin yazmak için sözcükleri seçerken ve cümleleri oluştururken özenli davranması kastedilmektedir (Hoffman, Teale ve Yokota, 2015). Çocuğun konuşma dilinde duyduğu ve ifade ettiği söz dizimsel yapıları ve dilbilgisine ait kuralları kitaplardaki metinler aracılığıyla tekrar duyması, dilin yapısına olan aşinalığını arttırmaktadır. Çocuklara yönelik öykü kitapları, dil gelişimi açısından çocukların duymaları gereken bir zenginliğe ve niteliğe sahip olmalı; bu özellikler açısından yüksek niteliğe sahip metinler seçilmesi gerekmektedir (Barnes, Grifenhagen ve Dickinson, 2016; Tüfekçi-Can, 2014).

Ileti. İleti (ana düşünce) yazarın tema ve konu çerçevesinde okurla paylaşmak istediği asıl düşüncedir. Yazınsal nitelik taşıyan bir kitabın amacı, bilgi aktaran öğretici metinlerin aksine çocukların sezme, duyma, düşünme becerilerini geliştirmek, çocuklara duyarlılık kazandırmaktır (Sever, 2008). Çocuklar için yazılmış bir öykü kitabının iletisinin çocuklara didaktik bir yolla değil, onların kendi anlamlarını çıkarmalarını ve kendi yorumlarını sağlayacak şekilde verilmesine dikkat 
edilmesi gerekmektedir. (Wolfenbarger ve Sipe, 2007). Didaktik öğelerin hâkim olduğu bir öyküde, öykünün kendisi değil, ahlaki bir mesaj ya da bir ders kaygısı öne çıkmaktadır. Çocukların dünyalarını genişletmeye katkıda bulunmayan bu durum çocuklar açısından uygun görülmemektedir (Anderson, 2013).

\section{Resimleme Özellikleri}

Resimli öykü kitapları, çocukların en sık karşılaştıkları çocuk edebiyatı türü olmasının yanı sıra günlük hayatın içinde çocuklara yüksek niteliğge sahip resimlemeler sunarak, onların görsel ve estetik algılarını desteklemektedir (Sipe, 2008). Görseller günümüzde hayatın her alanında yaygın olarak kullanılmakta olup okul öncesi döneme hitap eden çocuk kitaplarındaki en önemli öğelerden birisini oluşturmaktadır. Görsel öğeler, resimli öykü kitabında yer verilen konunun, anlatılan olayların çocukların zihinlerinde canlandırmalarına olanak sağlamaktadır. Resimler üzerine yapılan konuşmalar çocukların dinleme ve konuşma becerilerinin gelişimine katkıda bulunmaktadır. Kitaplardaki resimlerle yaşanılan iletişim süreci, çocukların işitme, bakma, görme ve imgeleme yetilerini geliştirmelerini sağlayarak soyut kavramları algılamalarını kolaylaştırmaktadır. Kavram gelişimi açısından temel okuryazarlık eğitiminden önce çocukların görsel okuryazarlık becerilerinin geliştirilmesine öncelik verilmesi gerekmektedir (Karatay, 2011; Sever, 2008).

Okul öncesi dönemde çocuklar kitap okuma sırasında kitaptaki yazılardan çok resimlemelere bakmakta (Evans ve Saint-Aubin, 2005) ve öykünün anlamını daha çok resimlere bakarak çıkarmaktadırlar (Yaden, Smolkin ve MacGillivray, 1993). Verhallen ve Bus (2011), öykü kitabında yer alan resimlemelerin çocukların öykünün anlamını kavramalarında etkili olduğunu ortaya çıkarmışlardır. Greenhoot, Beyer ve Curtis (2014) tarafından yapılan çalışmada, ebeveynlere resimli ve resimli olmayan öyküler verilmiştir. Resimli olan öykülerin okunması sırasında çocuklar ve ebeveynler arasında resimli olmayan öykülerin okunması ile karşılaştırıldığında daha fazla sözel ve sözel olmayan iletişim sağlandığı ve çocukların öyküdeki olayları daha iyi hatırladıkları bulunmuştur. Öykü kitabındaki resimlemeler çocukların dikkatini çekmekte ve öyküyü anlamalarında etkili olmaktadır. Resimli kitapların çeşitli özellikleri çocukların bilgiyi işleme yeteneklerini farklı şekilde etkileyebilmektedir. Ganea ve Canfield (2015) tasvir edilen nesneleri açı bir şekilde temsil eden resimlerin, çocukların kitap tasvirleri ile gerçek dünya arasında bağlantı kurma konusunda destekleyebileceğini belirtmektedir.

Okul öncesi dönemde çocuklar öyküleri resimlerle anlamlandırdıkları için resimlemede kullanılan renklerin, çizgilerin ve şekiller metnin anlamını yansıtmak açısından dengeli ve düzenli bir şekilde bir araya getirilmesi; resimlemedeki bu detayların metni iyi yansıtması ve metinde geçenlerle çelişmemesi gerekmektedir. Resimlemelerin öyküyü yansıtacak güçte olmasına ve resmin ait olduğu 
metnin yanında yer almasına dikkat edilmesi de gerekmektedir (Bassa, 2103; Gönen, 2013; LynchBrown, Tomlinson ve Short, 2011). Öyküyü hem metin hem de resimler birlikte anlatmakta ve bu iki öğe, etki oluşturmada eşit derecede önem taşımaktadır. Bu nedenle metin ve resim uyumu resimli öykü kitaplarının sahip olması gereken en önemli özelliklerden birisi olarak karşımıza çıkmaktadır (Martinez ve Harmon, 2012; Nikolajeva ve Scott, 2019; Sipe, 2008).

Okul öncesi çocuklar için hazırlanan kitaplarda resimlerin, metne göre daha fazla yer tutması ve sayfaların dörtte üçlük oranda (3/4) resimlerden oluşması gerekmektedir. Okumayı öğrenen çocuklara yönelik kitaplarda bu oran azaltılarak resim ve metin arasında bir denge kurulmaya çalışılmaktadır. 9-12 yaş grubundaki çocuklara yönelik hazırlanan kitaplarda resimler yerini, metinlere bırakmaya başlamaktadır. Yaş düzeylerine göre metin resim oranları 2-7 yaş için kitabın 1/4'ü yazı, 3/4'ü resim; 7-9 yaş için 2/4'ü yazı, 2/4'ü resim; 9-12 yaş ve üstü için 3/4'ü yazı, 1/4'ü resim olarak belirtilmektedir (Karatay, 2011).

Görsel ve sözel anlatıları kitap biçiminde birleştirme özelliğine sahip olan resimli öykü kitaplarındaki resimlemelerde yağlı boya, akrilik, suluboya ve kurşun kalem gibi çeşitli araçlar kullanılmaktadır (Pilgrim ve Ward, 2017). Resimli öykü kitaplarındaki resimlemeler görsel okuryazarlık gelişimi açısından oldukça önem taşımaktadır. Yüksek nitelikli görsellere sahip olan öykü kitapları çocuklarda görsel bir estetik anlayışın geliştirilmesinde etkili olmaktadır. Bu nedenle çocuk kitaplarında resimlemelerin ticari kaygı taşımadan, yaratıcı fikirlerle ve bilinçli bir şekilde kullanılmış renk ve çizim teknikleriyle oluşturulması gerekmektedir. Özensiz ve tek düze resimler kullanılmamalı; nitelikli bir resimleme için çizerin metni iyi anlaması, mekânı ve tipleri bu anlam doğrultusunda oluşturması önem kazanmaktadır (Bassa, 2013; Hancock, 2007).

Çocuk edebiyatı çocukların ilgilerini, yönelik olarak onların ilgilerini ve isteklerini ele almaktadır. Böylece öğretim için ilgi çekici ve motive edici eğitici bir araç görevi üstlenmektedir (Ghosn, 2013). Resimli öykü kitapları duyuları harekete geçirmeye yönelik çeşitli tasarım öğelerini ve biçimlerini kullanarak çocukların etkili bir şekilde öğrenmelerine yardımcı olacak okuma materyalleri olarak kullanılmaktadır. Öğretmenlerin, ebeveynlerin, çocuk kitabı yazarlarının ve çizerlerinin çocukların tercihlerinin, ilgi ve ihtiyaçlarının farkında olmaları gerekmektedir (Wei ve Ma, 2020). Nitelikli bir çocuk kitabının hazırlanmasında yazarın, çizerin, editörün uyum içinde çalışmaları ve çocuk edebiyatı ile ilgili gelişmeleri takip etmeleri önem kazanmaktadır (Körükçü, 2012).

Ülkemizde son yıllarda okul öncesi dönem çocuklarına yönelik hazırlanan resimli öykü kitaplarının sayısında artış olduğu görülmektedir. Bu durum çocuk kitaplarının daha fazla çocuğa ulaşması ve çocukların pek çok farklı kitapla tanışması açısından olumlu bir gelişme olsa da çocuk gelişimine uygun olmayan ve sadece ticari amaç taşıyan kitapların sayısında da artış olduğu görülmektedir. 
Resimli öykü kitapları çocukların bilişsel, sosyal-duygusal ve dil gelişimlerini destekleyen önemli bir araçtır. Bu kitapların çocukların gelişimlerinde ve öğrenmelerinde önemli yer tutabilmeleri, okuma alışkanlığını erken yaşta kazanmalarında etkili olabilmeleri ve çocuklara keyif verebilmeleri için biçimsel, içerik ve resimleme özellikleri açısından belli kriterlere sahip olmaları gerektiği görülmektedir. Çocukların okul, ev ve kütüphane ortamlarında nitelikli çocuk edebiyatı ürünleri ile karşılaşmaları oldukça önem taşımaktadır. Bu nedenle yetişkinlerin, çocukların gelişimsel alanlarını en iyi şekilde destekleyebilmeleri için nitelikli olan ve olmayan kitapları birbirinden ayırabilmeleri gerekmektedir. Horning (2010) çocuk kitabı sayısındaki artışın özellikle ebeveynler ve öğretmenler açısından kitap seçimini daha önemli hale getirdiğini ve çocuklara en iyi kitapları seçebilmek için eleştirel becerilerini geliştirmeleri gerektiğini belirtmektedir.

Resimli öykü kitaplarının değerlendirilmesine yönelik olarak ilgili literatür incelendiğinde, resimli öykü kitaplarının biçim, içerik ve resimleme özellikleri kapsamında kitap inceleme formlarının ve kontrol listelerinin oluşturulduğu görülmektedir (Demircan, 2006; Gönen ve diğerleri, 2016; Körükçü, 2012; Yıldız, Yazıcı ve Durmuşoğlu, 2016). Bu çalışmada resimli öykü kitaplarının niteliğini belirlemeye yönelik geçerli ve güvenilir bir ölçme aracının geliştirilmesi amaçlanmaktadır. Araştırmada “Resimli Öykü Kitaplarını Değerlendirme Ölçeği geçerli ve güvenilir midir?” sorusuna yanıt aranmıştır. Resimli öykü kitaplarının niteliğini belirlemeye yönelik bir ölçeğin geliştirilmesinin araştırmacılar, öğretmenler, ebeveynler, kütüphaneciler, çocuk gelişimi uzmanları, yayıncılar, yazarlar ve çizerler tarafindan kullanılabileceği düşünülmektedir.

\section{YÖNTEM}

Bu araştırma resimli öykü kitaplarının niteliğinin belirlenmesi amacıyla hazırlanan Resimli Öykü Kitaplarını Değerlendirme Ölçeğinin geçerlik ve güvenirlik analizlerini içeren bir ölçek geliştirme çalışmasıdır. Bu bölümde, Resimli Öykü Kitaplarını Değerlendirme Ölçeği’ni geliştirme çalışmasının hangi aşamalarda gerçekleştiğine, çalışma materyaline ve verilerin analizinde kullanılan istatistiksel işlem ve tekniklere yer verilmiştir.

\section{Çalışma Materyali}

Ölçeğin geçerlik ve güvenirlik çalışması tesadüfi örnekleme yöntemiyle seçilen 200 resimli öykü kitabı ile yapılmıştır. Bu tür örneklem seçimi, araştırmacının saptanan örneklem büyüklüğüne göre herhangi bir şekilde evrenin bir parçasını seçmesi ile gerçekleşmektedir (Kılıç, 2013). Çalışma materyalini oluşturan resimli öykü kitaplarının yayınevi, yayın yılı ve çeviri kitap olup olmadıkları ile ilgili bilgilere Tablo 1'de yer verilmiştir. 
Tablo 1. Çalışma materyalinde yer alan resimli öykü kitaplarının özellikleri

\begin{tabular}{|c|c|c|c|c|c|}
\hline Yayınevi & $\mathbf{F}$ & $\%$ & Yayınevi & $\mathrm{f}$ & $\%$ \\
\hline Timaş & 16 & 8.0 & Uçan Balık & 5 & 2.5 \\
\hline Türkiye İş Bankası Yayınları & 14 & 7.0 & Doğan Egmont Yayıncılık & 4 & 2.0 \\
\hline 1001 Çiçek & 12 & 6.0 & Kök Yayıncılık & 4 & 2.0 \\
\hline Morpa & 12 & 6.0 & Marsik Kitap & 4 & 2.0 \\
\hline Tübitak Popüler Bilim Kitapları & 12 & 6.0 & Nesin Yayınevi & 4 & 2.0 \\
\hline Yap1 Kredi Yayınlar1 & 12 & 6.0 & Odtü Yayıncılık & 4 & 2.0 \\
\hline $\mathrm{Ya}-\mathrm{Pa}$ & 8 & 4.0 & Redhouse Kidz & 4 & 2.0 \\
\hline Gönül Yayıncılık & 7 & 3.5 & Bulut Yayınları & 3 & 1.5 \\
\hline Mavi Bulut & 7 & 3.5 & Çilek Kitaplar & 3 & 1.5 \\
\hline Pearson Çocuk Kitapları & 7 & 3.5 & Ĕğiten Çocuk & 3 & 1.5 \\
\hline Nesil Yayıncılık & 6 & 3.0 & İletişim & 3 & 1.5 \\
\hline Altın Kitaplar & 5 & 2.5 & Kaknüs Yayıncılık & 3 & 1.5 \\
\hline Can Çocuk & 5 & 2.5 & Kuraldışı & 3 & 1.5 \\
\hline Epsilon & 5 & 2.5 & Uçan Fil & 3 & 1.5 \\
\hline Kırmız1 Kedi & 5 & 2.5 & Tudem & 3 & 1.5 \\
\hline Mutlu Yayıncılık & 5 & 2.5 & AÇEV & 2 & 1.0 \\
\hline Remzi Kitabevi & 5 & 2.5 & Elma Yayınevi & 2 & 1.0 \\
\hline Yayın Y11 & $\mathrm{f}$ & $\%$ & Yayın Y11 & $\mathbf{f}$ & $\%$ \\
\hline 2006 & 15 & 7.5 & 2012 & 24 & 12 \\
\hline 2007 & 11 & 5.5 & 2013 & 17 & 8.5 \\
\hline 2008 & 17 & 8.5 & 2014 & 12 & 6 \\
\hline 2009 & 15 & 7.5 & 2015 & 14 & 7 \\
\hline 2010 & 20 & 10 & 2016 & 14 & 7 \\
\hline 2011 & 41 & 20.5 & & & \\
\hline Özellik & $\mathrm{f}$ & $\%$ & Özellik & f & $\%$ \\
\hline Çeviri kitap & 107 & 53.5 & Çeviri olmayan kitap & 93 & 46.5 \\
\hline
\end{tabular}

\section{Ölçeğin Geliştirilme Süreci}

Ölçek geliştirilirken; alanyazın tarama, madde havuzu oluşturma, uzman görüşü alma, uzman görüşlerini değerlendirme, ölçeğin çalışma materyali üzerinde uygulanması ve verilerin analizi süreçleri izlenmiştir.

\section{Madde havuzu oluşturma}

Ölçek geliştirmenin ilk aşamasında alanyazın incelenmiştir. Alanyazından edinilen bilgiler ışı̆̆ında resimli öykü kitaplarının sahip olması gereken resimleme ve içerik özellikleri belirlenmiş ve toplam 22 maddeden oluşan bir madde havuzu oluşturulmuştur. Bu maddelerin 8 tanesi resimleme özellikleri, 14 maddesi ise içerik özellikleri ile ilgili olarak hazırlanmıştır. Resimleme özellikleri ile ilgili maddelerde kapak resmi ve kitabın iç sayfalarındaki resimler ve renk özellikleri, resimlerin çocukların gelişim düzeyine uygunluğu, metin-resim ilişkisi, sayfanın yarısından fazlasının resimlerden oluşması gibi kitabın resimlemesinde dikkat edilmesi gereken özellikler göz önünde bulundurulmuştur. İçerik özellikleri kapsamında ise maddeler, öykünün dili, üslubu, konusu, temas1, karakterleri açısından çocukların gelişimlerine ve ihtiyaçlarına uygunluğuna yönelik olarak belirlenmiştir. Ölçek 3’lü likert tipine göre Yeterli (3), Kısmen yeterli (2), Yetersiz (1) olarak hazırlanmıştır. 


\section{Uzman görüşü alma}

Ölçek maddeleri kapsam geçerliliği için yedi uzmanın görüşüne sunulmuştur. Uzmanlara ait bilgilere Tablo 2'de yer verilmiştir.

Tablo 2. Resimli Öykü Kitaplarını Değerlendirme Ölçeği geçerlik çalışmasına katılan uzmanların özellikleri

\begin{tabular}{llll}
\hline Değişkenler & N & Değişkenler & $\mathbf{n}$ \\
\hline Eğitim düzeyi & & Çalışma alanı & \\
$\quad$ Lisans & 2 & Akademisyen & 5 \\
Doktora & 5 & Yazar & 1 \\
& & Çizer & 1 \\
\hline Not: $n=7$ & & &
\end{tabular}

Tablo 2'de görüldüğü gibi ölçeğin kapsam geçerliliği için görüş alınan uzmanların ikisi lisans, beşi doktora eğitimi düzeyindedir. Uzmanların çalışma alanları incelendiğinde beş uzmanın akademisyen, bir uzmanın yazar, bir uzmanın da çizer olduğu görülmektedir. Uzmanlar bir ölçme ve değerlendirme uzmanı, üç okul öncesi eğitimi alanı uzmanı, bir çocuk kitapları yazarı, bir çocuk kitapları çizeri ve bir de dil uzmanı olarak belirlenmiştir.

Uzman görüssleri, maddelerin uygun ya da uygun değil olarak değerlendirilmesine yönelik alınmış olup uzmanlardan eğer varsa her madde ile ilgili önerilerini yazmaları istenmiştir. Değerlendirilen uzman görüşlerine göre resimleme ve içerik özelliklerine ait birer maddenin ifadeleri düzenlenmiştir. İçerik özelliklerinden bir maddenin iki ayrı maddede ele alınmasını öneren uzman görüşleri dikkate alınmış; bu maddede yer alan kriterler iki ayrı maddede ifade edilmiştir. Böylece içerik özellikleri ile ilgili madde sayısı 15 madde olmuş, resimleme özellikleri ile ilgili 8 madde eklendiğinde ölçeğin toplam madde sayısı da 23 olmuştur. Bu aşamadan sonra ölçek çalışma materyali bölümünde özellikleri verilen 200 resimli öykü kitabına uygulanmıştır.

\section{Verilerin Toplanması ve Analizi}

Resimleme ve içerik özelliklerine dair oluşturulan 23 madde ve her maddenin nasıl değerlendirileceğine yönelik oluşturulan açılamalar kapsamında resimli öykü kitapları araştırmacı tarafından incelenmiştir. Önce kitapta yer alan öykünün metni baştan sonra okunmuş sonrasında her sayfadaki resimler incelenmiştir. Kitaplar en az iki kere belirtilen şekilde okunup incelendikten sonra her madde kriteri karşılama düzeyine göre üçlü likert tipinde yeterli (3), kısmen yeterli (2), yetersiz (1) şeklinde değerlendirilmiş ve ölçek maddeleri puanlanmıştır. Bir kitap için ölçeğin doldurulma süresi ortalama 25-30 dakika olarak gerçekleştirilmiştir. 


\section{BULGULAR}

Bu bölümde Resimli Öykü Kitaplarını Değerlendirme Ölçeğinin geliştirilmesi sürecinde yapılan analizlere ve bu analizlere ilişkin yorumlara yer verilmiştir.

Tablo 3. KMO ve Barlett's testi değerleri

\begin{tabular}{llr}
\hline Kaiser-Meyer-Olkin Örneklem Yeterlilĭ̆i & .924 \\
& Ki-kare Değeri & 3183.840 \\
Bartlett's Testi & Serbestlik Derecesi & 253 \\
& P & .000 \\
\hline
\end{tabular}

Açımlayıcı faktör analizi yapılmadan önce verilerin faktör analizine uygunluğu KMO (KaiserMeyer-Olkin) ve Bartlett küresellik testiyle belirlenmiştir ve Tablo 3’te KMO değerinin .92 olduğu görülmektedir. Bu bulgu örneklem büyüklüğünün faktör analizi için "mükemmel derecede yeterli” (Çokluk, Şekercioğlu ve Büyüköztürk, 2012, s. 207) olduğunu göstermiştir. Ayrıca Bartlett küresellik testi sonuçları incelendiğinde elde edilen ki-kare değerinin manidar olduğu görülmüştür $\left(\mathrm{X}_{(253)}^{2}=\right.$ 3183.840; p <0.01). Bu doğrultuda, verilerin çok değişkenli normal dağılımdan geldiği kabul edilmiştir. Bartlett Küresellik testi ile kontrol edilebilen çok değişkenli normallik, tüm değişkenlerin ve bu değişkenlerin doğrusal kombinasyonlarının normal dağıldığı varsayımıdır (Tabachnick ve Fidell, 2001). Bu test ki-kare istatistiğine dayanan bir istatistiktir ve manidarlık değerine bakıllır. Manidarlık değerinin 0.05 ’ten küçük olması çok değişkenli normallik varsayımının sağlandığı anlamına gelir. Bu ölçekte de $\mathrm{p}=0.00<0.05$ olduğundan çok değişkenli normallik varsayımı sağlanmıştır. Çok değişkenli normallik sağlandığı için doğrusallı̆̆ın da sağlandığı kabul edilmiştir. 200 örneklem büyüklüğü Comrey ve Lee (1992)'ye göre orta büyüklükte bir örneklemdir (Akt. Çokluk, Şekercioğlu ve Büyüköztürk, 2012).

\section{Açımlayıcı Faktör Analizi}

Yap1 geçerliği için faktör analizi uygulanarak yapının kuramsal olarak varsaydığı yapı ile uyum gösterip göstermediği incelenebilmektedir (Baykul, 2010; Çokluk, Şekercioğlu ve Büyüköztürk, 2012). Bu bağlamda Resimli Öykü Kitaplarını Değerlendirme Ölçeği için açımlayıcı faktör analizi yapılmıştır.

Resimli öykü kitaplarını değerlendirme ölçeği 2 alt boyut temel alınarak oluşturulmuştur. Bu alt boyutlar, resimleme özellikleri ve içerik özellikleridir. Bu çerçevede, aracın faktör desenini ortaya koymak amacıyla açımlayıcı faktör analizi yapılmıştır. Bu amaca yönelik faktörleştirme yöntemi olarak temel bileşenler analizi; döndürme yöntemi olarak da dik döndürme yöntemlerinden maksimum değişkenliği sağlayan varimax seçilmiştir. Yapılan analiz sonucunda, analize temel olarak 
23 madde için öz değeri 1'in üzerinde beş bileşen olduğu görülmüştür. Bu beş bileşenin toplam varyansa olan katkısının \%69.172 olduğu görülmektedir. Aşağıda, faktör sayısının belirlenmesine yönelik yığılma grafiğine yer verilmiştir.

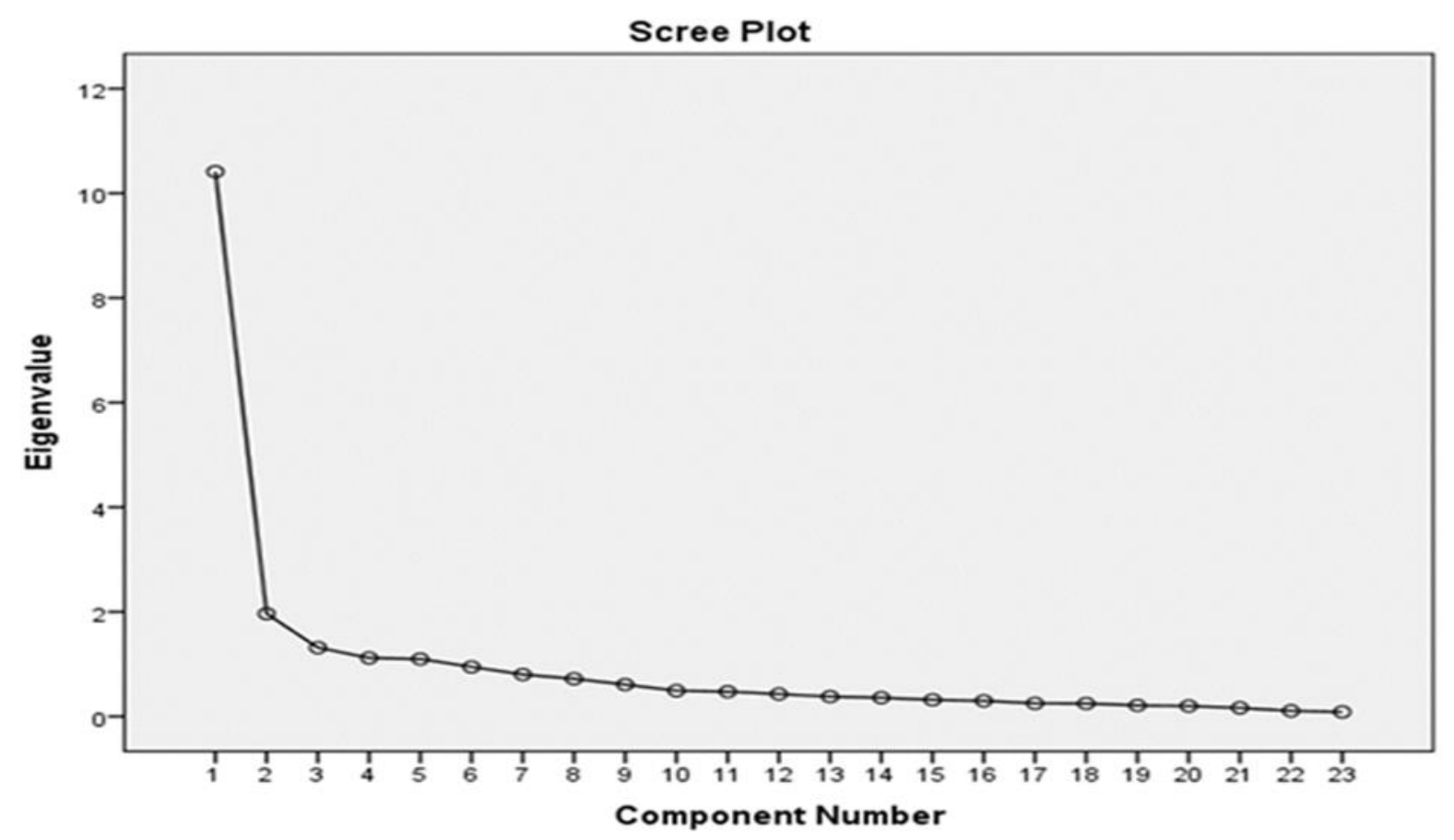

Şekil 1. Resimli Öykü Kitapların Değerlendirme Ölçeği Yığılma Grafiği

Bahsi geçen beş bileşen hem açıklanan toplam varyans hem de Şekil 1'de gösterilen yığılma grafiği ile birlikte incelendiğinde ve toplam varyansa yaptıkları katkının önemi çerçevesinde değerlendirildiğinde, ölçek bir faktörlü olarak değerlendirilebilir. Birinci faktörden ikinci faktöre geçerken yük değerinin 10'dan 2'ye yani 10/2=5 kat düştüğü görülmektedir. Birinciden ikinciye ani düşüş ölçeğin bir faktörlü olduğunu göstermektedir. Bu nedenle varyansa en önemli katkının da birinci faktörden kaynaklandığı ve ikinci bileşenden itibaren katkının giderek düşmesi durumuna dayalı olarak analizler yalnız bir faktörlü yapı için tekrarlanmıştır.

Bir faktör için tekrarlanan analizde, bu tek bir faktörlerin toplam varyansa yaptığı katkının \%45.274 olduğu görülmüştür. Resimli öykü kitaplarını değerlendirme ölçeğinin faktör desenini ortaya koymak amacıyla yürütülen açımlayıcı faktör analizinde, faktör yük değerleri için kabul düzeyi .32 olarak belirlenmiş ve faktör yükleri arasındaki fark .10'dan küçük olan maddeler binişik kabul edilmiştir. İncelenen değerlere göre i1 olarak ifade edilen "Öykünün isminin içerikle uyumlu olması" ve r2 olarak ifade edilen "Kapak resminin içeriğge uygun olması" maddeleri belirlenen minimum faktör yükü olan .32'nin altında kalmıştır. Bu nedenle, bu maddeler ölçek dış1 bırakılmıştır. Geriye kalan 21 maddelik ölçek tek faktörlü bir ölçeği oluşturmuştur. 
Düşük faktör yükü gösteren iki madde ölçek dışı bırakıldıktan sonra 21 madde ve tek faktör için yapılan açımlayıcı faktör analizi sonucunda ölçeğin varyansa yaptığı katkı \%48.927 olarak bulunmuştur. Maddelerin faktör yükleri Tablo 4'te gösterilmektedir.

Tablo 4. Resimli Öykü Kitaplarını Değerlendirme Ölçeği’nde yer alan maddelerin faktör yükleri

\begin{tabular}{|c|c|}
\hline Resimleme ve İçerik Özellikleri & Faktör 1 \\
\hline Kapak resmi ilgi çekicidir. & .606 \\
\hline Kitap sayfalarının yarısından fazlası resimlerden oluşmaktadır. & .414 \\
\hline Ayn sayfadaki metinler ve resimler birbiriyle uyumludur. & .664 \\
\hline Resimler estetik değer taşımaktadır. & .729 \\
\hline Resimler çocuğun gelişim düzeyine uygundur. & .736 \\
\hline $\begin{array}{l}\text { Kitaptaki karakterlerin özellikleri ve hareketleri (beden dili, duygular vb.) resimlere doğru } \\
\text { yansıttılmıstır. }\end{array}$ & .676 \\
\hline Resimlemede kullanılan renkler canlı ve dikkat çekicidir. & .704 \\
\hline Öykünün konusu çocuğun yaşına ve gelişim düzeyine uygundur. & .830 \\
\hline Öykünün konusu çocuklar açısından ilgi çekicidir. & .857 \\
\hline Öykü çocukların ruhsal ihtiyaçlarını giderecek niteliktedir. & .869 \\
\hline Öykü çocuğun yaratıcı hayal gücünü beslemektedir. & .671 \\
\hline Öyküde kullanılan dil açık, anlaşılır ve dil bilgisi açısından doğrudur. & .609 \\
\hline Öyküde kullanılan dil ve üslup çocukların yaşına ve gelişim düzeyine uygundur. & .791 \\
\hline Öykünün üslubu öğüt verici ve öğretici değildir. & .702 \\
\hline Öykü çocuğun sözcük dağarcığını geliştirecek niteliktedir. & .666 \\
\hline Öykünün ana fikri/teması açık, net ve anlaşılırdır. & .714 \\
\hline Öykünün giriş, gelişme ve sonuç bölümleri vardır. & .492 \\
\hline Öyküde yer alan karakterler çocuğun özdeşim kurması ve model alması için uygundur. & .837 \\
\hline Öykü etik ve evrensel değerlere (sevgi, sayg1, demokrasi vb.) önem vermektedir. & .726 \\
\hline Öykü dil, din, etnik köken, cinsiyet vb. açısından kalıp yargılar oluşturmamaktadır. & .594 \\
\hline Öykü çocuğa çözebileceği problemler sunmaktadır. & .612 \\
\hline
\end{tabular}

Maddelerin faktör yükleri incelendiğinde de 21 maddeden oluşan ölçekte faktör yüklerinin .414 ile .869 arasında değiştiği görülmektedir. Tablo 5’te ölçek maddelerinin madde toplam korelasyonlarına yer verilmiştir.

Tablo 5. Resimli Öykü Kitaplarını Değerlendirme Ölçeği’nde yer alan maddelerin madde toplam korelasyonlar1

\begin{tabular}{lc}
\hline Resimleme ve İçerik Özellikleri & $\begin{array}{c}\text { Düzeltilmiş } \\
\text { Madde Toplam } \\
\text { Korelasyon } \\
\text { Katsayssı }\end{array}$ \\
\hline Kapak resmi ilgi çekicidir. & .576 \\
Kitap sayfalarının yarısından fazlası resimlerden oluşmaktadır. & .379 \\
Aynı sayfadaki metinler ve resimler birbiriyle uyumludur. & .631 \\
Resimler estetik değer taşımaktadır. & .707 \\
Resimler çocuğun gelişim düzeyine uygundur. & .709 \\
Kitaptaki karakterlerin özellikleri ve hareketleri (beden dili, duygular vb.) resimlere doğru & .648 \\
yansıtılmıştır. & \\
Resimlemede kullanılan renkler canlı ve dikkat çekicidir. & .676 \\
Öykünün konusu çocuğun yaşına ve gelişim düzeyine uygundur. & .785 \\
Öykünün konusu çOcuklar açısından ilgi çekicidir. & .822 \\
Öykü çocukların ruhsal ihtiyaçlarını giderecek niteliktedir. & .832 \\
Öykü çocuğun yaratıcı hayal gücünü beslemektedir. & .640 \\
Öyküde kullanılan dil açık, anlaşlır ve dil bilgisi açısından doğrudur. & .562 \\
Öyküde kullanılan dil ve üslup çocukların yaşına ve gelişim düzeyine uygundur. & .745 \\
Öykünün üslubu öğüt verici ve öğretici değildir. & .663 \\
Öykü çocuğun sözcük dağarcığını geliştirecek niteliktedir. & .632 \\
Öykünün ana fikri/teması aç1k, net ve anlaşılırdır. & .671 \\
Öykünün giriş, gelişme ve sonuç bölümleri vardır. & .453
\end{tabular}


18 Öyküde yer alan karakterler çocuğun özdeşim kurması ve model alması için uygundur.

Tablo 5'e göre ölçekte yer alan maddelerin, madde toplam korelasyon katsayılarının .379 ile .832 arasında değiştiği görülmektedir. Ölçeğin toplanabilirlik özelliğinin bozulmaması için madde ile bütün arasındaki korelasyon katsayısının negatif olmaması ve .25 değerinden büyük olması beklenir (Kayış, 2009, s. 412). Buna göre ölçekte tüm maddelerin, madde toplam korelasyon katsayılarının bu şartı sağladığı görülmektedir.

\section{Güvenirlik}

Güvenirlik bir ölçme aracının duyarlılığı, kararlılığ ya da tutarlıllğı anlamlarında kullanılmaktadır. Ölçme araçlarının özelliklerini ortaya koymada en çok bir maddenin ölçekte yer alan diğer maddelerle yani ölçeğin bütünüyle tutarlılık gösterip göstermediği incelenir (Baykul, 2010). Yapılan ölçmelerin hatadan arınık olması için ölçeklerin güvenirliklerinin incelenmesi önem taşımaktadır. Tek uygulama ile güvenirlik belirleme yollarından en bilinenleri Kuder-Richardson (KR) güvenirlik katsayıları ve KR katsayılarının tüm olası yarılar için genelleştirilmiş hali olan Cronbach alfa katsayısıdır. Cronbach alfa ikiden daha fazla kategori ile puanlanan maddeler için uygundur (Anastasi, 1982; Baykul, 2010). Bu çalışmada kullanılan 21 maddelik Resimli Öykü Kitaplarını Değerlendirme ölçeğinin güvenirlik düzeylerinin incelenmesinde 3-2-1 olarak puanlanan 21 madde için Cronbach alfa katsayısı .94 olarak elde edilmiştir. Bu durumda ölçeğin güvenilir bir ölçek olduğu söylenebilir (George ve Mallery, 2003; Özdamar, 2002).

\section{Puanlayıc1 güvenirliği}

Puanlayıcı güvenirliği için geçerlik güvenirlik çalışması için seçilen 200 kitaptan 30’u başka bir okul öncesi eğitimi alan uzmanı tarafından değerlendirilmiştir. İki puanlayıcı arasındaki korelasyon katsayıs1 .92 olarak hesaplanmıştır. Korelasyon değerleri için, .30'dan küçük ise ilişkinin düşük, .30 ile .70 arasında ise orta ve .70 'den büyük olduğunda ise ilişkinin yüksek olduğu yorumu yapılmaktadır (Büyüköztürk, Çokluk-Bökeoğlu ve Köklü, 2015). Bu durumda iki puanlayıc1 arasında çok iyi uyuşma olduğu söylenebilir.

\section{SONUÇ ve TARTIŞMA}

Bu çalışmada, resimli öykü kitaplarının niteliğini değerlendirmek amacı ile alanyazın taraması sonucu içerik ve resimleme özellikleri ile ilgili hazırlanan 22 maddelik ölçme aracı 7 alan uzmanının görüşüne sunulmuş ve yapılan düzeltmeler sonucunda 23 maddelik 3'lü likert tipi bir ölçek oluşturulmuştur. Ölçeğin geçerlik ve güvenirlik çalışması tesadüfi örnekleme yöntemiyle seçilen 200 resimli öykü kitabı ile gerçekleştirilmiştir. 
Araştırmada, açımlayıcı faktör analizi yapılmadan önce verilerin faktör analizine uygunluğu KMO (Kaiser-Meyer-Olkin) ve Bartlett Sphericity testiyle belirlenmiş ve KMO değeri .92, Barlett's testi sonucu ise 3183.840 bulunmuştur. Yapılan analiz sonucunda, analize temel olarak 23 madde için öz değeri 1'in üzerinde beş faktör olduğu görülmüştür. Maddelere ilişkin yığılma grafiği ile birlikte değerlendirildiğinde ölçeğin tek boyutlu olarak değerlendirilebileceği biçiminde yorumlanmıştır. Varyansa en önemli katkının da birinci faktörden kaynaklandığı ve ikinci bileşenden itibaren katkının giderek düşmesi durumuna dayalı olarak analizler yalnız bir faktörlü yapı için tekrarlanmıştır. Bir faktör için tekrarlanan analizde, bu tek bir faktörlerin toplam varyansa yaptı̆̆1 katkının \%45.274 olduğu görülmüştür. Resimli öykü kitaplarını değerlendirme ölçeğinin faktör desenini ortaya koymak amacıyla yürütülen açımlayıcı faktör analizinde, faktör yük değerleri için kabul düzeyi .32 olarak belirlenmiş ve faktör yükleri arasındaki fark .10'dan küçük olan maddeler binişik kabul edilmiştir. İncelenen değerlere göre 2 madde belirlenen minimum faktör yükü olan .32'nin altında kalmıştır. Bu nedenle, bu maddeler ölçek dışı bırakılmıştır. Geriye kalan 21 maddelik ölçek tek faktörlü bir ölçeği oluşturmuştur. Düşük faktör yükü gösteren 2 madde ölçek dış1 bırakıldıktan sonra yapılan tek faktör için açımlayıcı faktör analizi yapılmıştır. Sonuç olarak 7 madde resimleme 14 madde içerik özellikleri olmak üzere toplam 21 madde ve tek faktörden oluşan ölçeğin varyansa yaptığı katkının \%48.927 olduğu ortaya çıkmıştır. Madde faktör yükleri .414 ile .869 arasında değişmektedir. Ölçekte yer alan maddelerin, madde toplam korelasyon katsayıları ise .379 ile .832 arasında değişmektedir.

Bu çalışmada ölçeğin güvenirlik düzeylerinin incelenmesinde 21 madde için Cronbach alfa katsayıs1 .94 olarak elde edilmiştir. Bu durumda ölçeğin güvenilir bir ölçek olduğu söylenebilir. Puanlayıcı güvenirliği için geçerlik güvenirlik çalışması için seçilen 200 kitaptan 30'u farklı bir okul öncesi eğitimi alanı uzmanı tarafından değerlendirilmiştir. İki puanlayıcı arasındaki korelasyon katsayısı .92 olarak hesaplanmıştır. Bu durumda iki puanlayıcı arasında çok iyi uyuşma olduğu görülmektedir.

Geçerlik ve güvenirlik çalışmaları sonucunda ölçek son haliyle tek boyuttan ve toplam 21 maddeden oluşmaktadır. Ölçekten alınabilecek en düşük puan 21 puan, en yüksek puan ise 63 puandır. Resimli öykü kitaplarının niteliği açısından ölçek puanlamasında 21 puan-34 puan arası yetersiz, 35 puan49 puan kısmen yeterli, 50 puan-63 puan yeterli olarak kabul edilmektedir. Ölçekten alınan puanların düşük olması resimli öykü kitabının niteliğinin yetersiz olduğunu belirtirken, yüksek puan alınması öykü kitabının niteliğinin yüksek olduğunu belirtmektedir.

Yapılan analizler sonucunda Resimli Öykü Kitaplarını Değerlendirme Ölçeği’nin resimli öykü kitapların niteliğini belirlemek açısından geçerli ve güvenir bir araç olduğu görülmektedir. 
Ülkemizde resimli kitapların niteliğine yönelik geliştirilmiş bir ölçek çalışmasına rastlanmamıștır. Son zamanlarda çocuklara yönelik yazılmış olan kitapların sayısında artış olmasından ve çocukların ilgi ve ihtiyaçlarına yönelik olarak kitap seçiminin daha da önem kazanmasından hareketle çocuklara yönelik yazılan kitapların seçiminde ve değerlendirilmesinde belirli bir standart oluşturulması amacıyla bu ölçek geliştirilmiştir.

Bir resimli öykü kitabını değerlendirirken önce kitabın içerik özelliklerinin ele alınması önerilmektedir. Kitabın teması, mesajı, karakterleri ve olayları ile ilgili fikir sahibi olunduğunda resimlerin sanatsal değerinin belirlenebileceğini, kitabı değerlendirecek kişi öykünün temasını anladığında, resimlerin genel estetiğe nasıl katkıda bulunduğunu daha iyi değerlendirebileceği belirtilmektedir (Hearne ve Sutton, 1993). Bu çalışmada da ölçek uygulamasında önce içerik özellikleri ile ilgili maddeler daha sonra resimlemeler ile ilgili maddeler değerlendirilmiştir.

Çocuk edebiyatı alanında çalışan uzmanların, öykünün dili ve resimleri açısından sanatsal değere sahip olma, toplumsal cinsiyet eşitliğine önem verme ve etnik ayrımcllık içermeme gibi gerekçelerle metin ve resimlemeler açısından yüksek niteliğe sahip, büyük ölçüde ödüllü çocuk kitaplarını önerdikleri görülmektedir (Fullerton ve diğerleri, 2018). Çocuk edebiyatı yazarlarının görüşlerine göre çocuk edebiyatında estetik ölçütlerin belirlenmesine yönelik yapılan çalışmada çocuk edebiyatı ürünlerine yönelik estetik ölçütler 'Çocuğun gelişim düzeyine uygun olma, dilinin, konusunun, kurgusunun, dış yap1 özelliklerinin nitelikli olması, çocuğa düşünme becerisi kazandırması, dil gelişimini geliştirme durumu, dil, anlatım, konu, biçim vb. özellikler açısından tutarlı olma, çocukta sanat alg1sı oluşturma, türüne özgü özellikler taşıma, öğretici olma, ideolojik söylemlerden uzak olma’ kriterleri kapsamında belirlenmiştir (Dedeoğlu-Orhan, 2019). Çer ve Şahin (2016) tarafından çocuk kitaplarını tasarım, içerik ve eğitsel özellikler açısından bütüncül bir yaklaşımla değerlendirmek amacıyla geliştirilen kontrol listesindeki kriterler çocuk kitaplarının; çocukların hayal etmelerine, özgürce düşünmelerine, karar vermelerine, şiddetle başa çıkmalarına, yaratıc1lı̆̆ teşvik etmelerine, inisiyatif kullanmalarına ve duygularından faydalanmalarına izin veren unsurlar taşıyıp taşımamaları kapsamında geliştirilmiş olup resimleme ve tasarım özellikleri ile ilgili kriterlere de yer verilmiştir. İçerik özellikleri de karakter, olay örgüsü, dil ve anlatım, ileti başlıklarında oluşturulmuştur. Bu araştırma kapsamında geliştirilen ölçek maddelerinin de bu çalışmalarda yer alan kriterle uyumlu olduğu görülmektedir.

Schwarz ve diğerleri (2015) resimleme özellikleri resimlerin sayısı, resimlerin yerleştirilmesi (metinresim uyumu), görsel çekicilik ve resimlerin öyküyü yansıtma düzeyi kriterleri kapsamında değerlendirildiğini belirtmektedir. Bu araştırmada yer alan resimlemeler ile ilgili maddelerin de bu kriterlere benzer şekilde oluşturulduğu görülmektedir. 
Resimli öykü kitapları kesin bir resimleme ve içerik yapısına sahip olmamakla birlikte bu çalışma kapsamında geliştirilen ölçek ile resimli öykü kitaplarının çocukların gelişimini destekleyebilmeleri için içerik ve resimleme özellikleri açısından belli kriterler çerçevesinde niteliklerinin değerlendirilebilmeleri amaçlanmıştır. Lee, Perger Dunn, ve O’Sullivan (2014) çocuk kitaplarını değerlendirmede aslında iyi bir kitabın gerektirdiği ana kriterlerin tam sayısının ve oranının mevcut olmadığını; çocuklara kitap seçerken belli özelliklere dikkat ederek hangi kitabın nitelikli ya da nitelikli olmadığına karar verme becerilerinin gelişiminde belli bir çerçeve sağlanabileceğini belirtmektedirler. Literatürde yaş grubuna uygun kitapları belirlerken hem nesnel hem de öznel değerlendirmeler yapılması önerilmektedir. Kitabın fiziksel özellikleri, resimleme özellikleri ve bilişsel gereksinimleri öznel görüşleri içermektedir. Nesnel ölçüm ise sözcük sayısı ya da cümle uzunluğunun ölçülerek metnin zorluk derecesinin belirlenmesi ile mümkün olmaktadır (Fry, 2002; Gunning, 2003). Bu çalışma kapsamında geliştirilen ölçek maddelerinde hem öznel hem de nesnel ölçüme dayalı kriterler bulunmaktadır.

Çocuk edebiyatında da diğer edebiyat türlerinde olduğu gibi okuyucuların öznel değerlendirmeleri etkili olmaktadır. Kitap seçerken kitapların daha bütüncül bir şekilde değerlendirilmesine yardımcı olmak için bu ölçeğin kullanılması önerilmektedir. Bu araştırma kapsamında geliştirilen resimli öykü kitaplarının niteliğinin belirlenmesine yönelik ölçme aracının, bu kitapların daha iyi incelenmelerini sağlayacağı, nitelikli kitapları çocuklarla buluşturmaya yardımcı olacağı ve çocuk edebiyatı ile ilgili alan yazına katkı sağlayacağı düşünülmektedir. Geliştirilen ölçeğin araştırmacılar, öğretmenler, ebeveynler, kütüphaneciler, çocuk gelişimi uzmanları, yayıncılar, yazarlar ve çizerler tarafindan kitap seçiminde kullanılabileceği düşünülmektedir. Farklı çocuk kitabı türlerinin farklı özellikler taşımasından ve çocukların farklı becerilerini destekleyeceklerinden hareketle farklı çocuk kitabı türleri için değerlendirme araçları oluşturulması önerilmektedir.

\section{KAYNAKÇA}

Anastasi, A. (1982). Psychological testing. New York: Macmillan Publishing Co, Inc.

Anderson, N. A. (2013). Elementary children's literature, infancy through age 13. New York: Pearson education.

Barnes, E. M., Grifenhagen, J. F. \& Dickinson, D. K. (2016). Academic language in early childhood classrooms. The Reading Teacher, 70(1), 39-48.

Bassa, Z. (2013). Çocuk kitaplarında resimleme. M. Gönen (Ed.), Çocuk edebiyatı (ss. 179-221) içinde. Ankara: Eğiten Kitap.

Baykul, Y. (2010). Eğitimde ve psikolojide ölçme: Klasik test teorisi ve uygulaması. Ankara: Pegem Akademi. 
Blewitt, P., Rump, K.M., Shealy, S.E., \& Cook, S. A. (2009). Shared book reading: When and how questions affect young children's word learning. Journal of Educational Psychology, 101 (2), 294 304.

Büyüköztürk, Ş., Çokluk-Bökeoğlu, Ö. ve Köklü, N. (2015). Sosyal bilimler için istatistik. Ankara: Pegem Akademi Yayınları.

Cameron-Faulkner, T., \& Noble, C. (2013). A comparison of book text and child directed speech. First Language, 33(3), 268-279.

Clark, C., \& Foster, A. (2005). Children's and young people's reading habits and preferences: The who, what, why, where and when. London: National Literacy Trust.

Crain-Thoreson, C., Dahlin, M. P., \& Powell, T. A. (2001). Parent-child interaction in three conversational contexts: Variations in style and strategy. New Directions for Child and Adolescent Development, 92, 23-38.

Cramer, R. L. (2004). The language arts: A balanced approach to teaching, reading, writing, listening, talking, and thinking. Allyn \& Bacon.

Çer, E., \& Şahin, E. (2016). Validity of a checklist for the design, content, and instructional qualities of children's books. Journal of Education and Practice, 7(24), 128-137.

Çokluk, Ö., Şekercioğlu, G. ve Büyüköztürk, Ş. (2012). Sosyal bilimler için çok değğşkenli istatistik ve lisrel uygulamalar. Ankara: Pegem Akademi.

Dedeoğlu-Orhan, B. (2019). Cocuk edebiyatında estetik ölçütlerin belirlenmesi ve bir çocuk edebiyatı kitabının estetik ölçütler açısından değerlendirilmesi (Doktora tezi). Gazi Üniversitesi, Eğitim Bilimleri Fakültesi, Ankara.

Demircan, C. (2006). TÜBİTAK Çocuk Kitaplığ dizisindeki kitapların dış yapısal ve iç yapısal olarak incelenmesi. Mersin Üniversitesi Ë̈itim Fakültesi Dergisi, 2(1), 12-27.

Dickinson, D. K., \& Keebler, R. (1989). Variation in preschool teachers' styles of reading books. Discourse Processes, 12(3), 353-375.

Dockett, S., Perry, B., \& Whitton, D. (2006). Picture storybooks and starting school. Early Child Development and Care, 176, 835-848.

Evans, M. A., \& Saint-Aubin, J. (2005). What children are looking at during shared storybook reading. Psychological Science, 16, 913-920.

Fry, E. (2002). Readability versus leveling. The Reading Teacher, 56, 286-291.

Fullerton, S. K., Schafer, G. J., Hubbard, K., McClure, E. L., Salley, L., \& Ross, R. (2018). Considering quality and diversity: An analysis of read-aloud recommendations and rationales from children's literature experts. New Review of Children's Literature and Librarianship, 24(1), 76-95.

Ganea, P. A., \& Canfield, C. (2015). Learning from picture books: From infancy to early school days. B. Kummerling-Meibauer, J. Meibauer, K. Nachtigaller ve K, Rohlfing (Ed.), Learning 
from picturebooks: Perspectives from child development and literacy studies (ss. 33-50) içinde. New York: Routledge.

George, D., \& Mallery, P. (2003). SPSS for Windows step by step: A simple guide and reference. Boston: Allyn \& Bacon.

Ghosn, I. (2013). Humanizing teaching English to young learners with children's literature. Children's Literature in English Language Education Journal, 1(1), 39-57.

Gönen, M., Karakuş, H., Uysal, H., Kehci, A., Ulutaş, Z. ve Kahve, O. (2016). Resimli çocuk kitaplarının içerik ve resimleme özelliklerinin bazı değişkenler açısından incelenmesi. Hacettepe Üniversitesi Eğitim Fakültesi Dergisi, 31(4),724-735.

Gönen, M. (2013). Cumhuriyet öncesi ve cumhuriyet döneminde okul öncesi çocuk edebiyatı. M. Gönen (Ed.), Cocuk edebiyatı (ss. 15-31) içinde. Ankara: Eğiten Kitap.

Gönen, M. ve Veziroğlu, M. (2013). Çocuk edebiyatının genel hedefleri. M. Gönen (Ed.), Çocuk Edebiyatı (ss. 1-11) içinde. Ankara: Eğiten Kitap.

Greenhoot, A. F., Beyer, A. M., \& Curtis, J. (2014). More than pretty pictures? How illustrations affect parent-child story reading and children's story recall. Frontiers in Psychology, 5, 738.

Gunning, T. G. (2003). The role of readability in today's classrooms. Topics in Language Disorders, 23(3), 175-189.

Güleryüz, H. (2003). Yaratıcı çocuk edebiyatı. Ankara: Pegem Yayıncilık.

Hancock, M. R. (2007). Language arts: Extending the possibilities. Upper Saddle River, NJ: Pearson.

Hayes, D. P., \& Ahrens, M. G. (1988). Vocabulary simplification for children: A special case of 'motherese'? Journal of Child Language. 15, 395-410.

Hearne, B., \& Sutton, R. (Ed.). (1993). Evaluating children's books: A critical look: Aesthetic, social, and political aspects of analyzing and using children's books. Urbana-Champaign, IL: University of Illinois, Graduate School of Library and Information Science.

Hoffman, J. L., Teale, W. H., \& Yokota, J. (2015). The book matters! Choosing complex narrative texts to support literary discussion. Young Children, 70(4), 8-15.

Hoffman, J. L. (2011). Coconstructing meaning: interactive literary discussions in kindergarten read-alouds. The Reading Teacher, 65(3), 183-194.

Horning, K. T. (2010) From cover to cover: Evaluating and reviewing children's books. New York: Harper Collins.

Horst, J. S., \& Houston-Price, C. (2015). An open book: What and how young children learn from picture and story books. Frontiers in psychology, 6, 1719.

Işıtan, S. (2013). Kitap okuma modelleri ve öykü sonrası etkinlikler. M. Gönen (Ed.), Cocuk edebiyatı (ss. 251-262) içinde. Ankara: Eğiten Kitap. 
Işıtan, S. ve Gönen, M. (2006). Resimli çocuk kitaplarının benlik kavramıyla ilgili konuları içermesi yönünden incelenmesi. II. Ulusal Cocuk ve Gençlik Edebiyatı Sempozyumu Bildiri Kitabı, 413-420. Ankara: Ankara Üniversitesi Eğitim Bilimleri Fakültesi.

Jalongo, M. R. (2004). Young children and picture books. Washington DC: National Association for the Education of Young Children.

Justice, L.M., Pullen, P., \& Pence, K. (2008). Influence of verbal and nonverbal references to print on preschoolers' visual attention to print during storybook reading. Developmental Psychology, 44(3), 855-866.

Karatay, H. (2011). Çocuk edebiyatı metinlerinde bulunması gereken özellikler. T. Şimşek (Ed.), Kuramdan uygulamaya çocuk edebiyatı el kitabı (ss. 77-125) içinde. Ankara: Grafiker Yayınları.

Kayış, A. (2009). Güvenirlik analizi. Ş. Kalayc1 (Ed.), SPSS uygulamalu çok değişkenli ustatistik teknikleri (ss. 403-419) içinde. Ankara: Asil Yayıncılık.

Körükçü, Ö. (2012). Okulöncesi eğitime yönelik resimli çocuk kitaplarının bulunması gereken temel özellikler açısından incelenmesi. Trakya Üniversitesi Sosyal Bilimler Dergisi, 14(2), 243-254.

Lane, H. B. \& Wright, T. L. (2007). Maximizing the effectiveness of reading aloud. The Reading Teacher, 60(7), 668-675.

Lee, K., Perger, P., Dunn, M. ve O'Sullivan, J. (2014). How do you know if it is any good? The development and application of an evaluative framework to assess contemporary children's books. V. C. X. Wang (Ed.), Handbook of research on education and technology in a changing society. (ss. 1-15) içinde. Florida, USA: IGI Global.

Lynch-Brown M. C., Tomlinson M. C., \& Short G. K. (2011). Essentials of children's literature. Pearson.

Mac Naughton, G. \& Williams, G. (2009). Teaching young children: Choices in theory and practice. UK: McGraw-Hill Education

Mallan, K. (2017). Children's literature in education. http://education.oxfordre.com/view/10.1093/acrefore/9780190264093.001.0001/acrefor e-9780190264093-e-157. (Erişim Tarihi: 27.07.2020)

Martinez, M., \& Harmon, J. (2012). Picture/text relationships: An investigation of literary elements in picturebooks. Literacy Research and Instruction, 51(4), 323-343.

McGee, L. M., \& Schickedanz, J. A. (2007). Repeated interactive read-alouds in preschool and kindergarten. The Reading Teacher, 60, 742-751.

Mol, S. E., Bus, A. G., De Jong, M. T., \& Smeets, D. J. (2008). Added value of dialogic parentchild book readings: A meta-analysis. Early Education and Development, 19(1), 7-26.

Montag, J. L., Jones, M. N., \& Smith, L. B. (2015). The words children hear: Picture books and the statistics for language learning, Psychological Science, 26(9): 1489-1496. 
Muhinyi, A., Hesketh, A., Stewart, A. J., \& Rowland, C. F. (2020). Story choice matters for caregiver extra-textual talk during shared reading with preschoolers. Journal of Child Language, 47(3), 633-654.

Neuman, S. B. \& Roskos, K. (2007). Nurturing knowledge: Building a foundation for school success by linking early literacy to math, science, art and social studies. New York: Scholastic.

Nikolajeva, M., \& Scott, C. (2019). How picturebooks work. New York \& London: Routledge.

Nodelman, P., \& Reimer, M. (2003). The pleasures of children's literature. Boston: Allyn and Bacon

Norton, D., \& Norton, S. (2010). Through the eyes of a child: An introduction to children's literature. Boston, MA: Prentice-Hall.

Oğuzkan, F. (2013). Çocuk edebiyatı. Ankara: Anı Yayınc1lik.

Özdamar, K. (2002). Paket programlarla istatistiksel veri analiæi-1. Eskişehir: Kaan Kitabevi.

Pilgrim, J., \& Ward, A. K. (2017). Universal design for learning: A framework for supporting effective literacy instruction. C. M. Curran ve A. J. Peterson (Ed.), Handbook of research on classroom diversity and inclusive education practice (ss. 282-310) içinde. Hershey, PA: IGI Global.

Price, L. H., van Kleeck, A., \& Huberty, C. J. (2009) Talk during book sharing between parents and preschool children: A comparison between storybook and expository book conditions. Reading Research Quarterly 44(2), 171-194.

Robertson, S. J. L., \& Reese, E. (2017). The very hungry caterpillar turned into a butterfly: Children's and parents' enjoyment of different book genres. Journal of Early Childhood Literacy, 17(1), 3-25.

Russell, D. (2014). Literature for children a short introduction. USA-Boston: Pearson.

Schwarz, A. L., van Kleeck, A., Beaton, D., Horne, E., MacKenzie, H., \& Abdi, H. (2015). A readaloud storybook selection system for prereaders at the preschool language level: A pilot study. Journal of Speech, Language, and Hearing Research, 58(4), 1273-1291.

Sever, S. (2013). Çocuk edebiyatı ve okuma kültürü. İzmir: Tudem Yayınları.

Sever, S. (2008). Cocuk ve edebiyat. İzmir: Tudem Yayınları.

Short, K. G. (2011). What's trending in children's literature and why it matters. Language Arts, 95(5), 287-298.

Sipe, L. R. (2008). Storytime: Young children's literary understanding in the classroom. New York: Teachers College Press.

Stagg Peterson, S., \& Swartz, L. (2008). Good books matter: How to choose and use children's literature to help students grow as readers. Ontario: Pembroke Publishers.

Stebler, M. Z. (2012). Yaş gruplarına göre çocuk kitapları. T. Şimşek (Ed.), Kuramdan uygulamaya cocuk edebiyatı el kitabı (ss. 132-144) içinde. Ankara: Grafiker Yayınları. 
Tabachnick, B. G., \& Fidel, L. S. (2001). Using multivariate statistics. MA: Allyn \& Bacon, Inc.

Teale, W. H. (2003). Reading aloud to young children as a classroom instructional activity: Insights from research and practice. A. van Kleeck, S. A. Stahl ve E.B. Bauer (Ed.), On reading books to children: Parents and teachers (ss. 114-139) içinde. Mahwah, NJ: Erlbaum.

Temple, C. A., Martinez, M., Yokota, J., \& Naylor, A. (2006). Children's books in children's hands: An introduction to their literature. Pearson Allyn and Bacon.

Tüfekçi Can, D. (2014). Cocuk edebiyatı kuramsal yaklaşım. Konya: Eğitim Kitabevi

Tür, G. ve Turla, A. (1999). Okul öncesinde çocuk, edebiyat ve kitap. İstanbul: Ya-Pa Yayınları.

Ural, S. (2013). Okul öncesi çocuk kitaplarının tanıtımı. M. Gönen (Ed.), Cocuk edebiyatı (ss. 33-55) içinde. Ankara: Eğiten Kitap.

Uzuner-Yurt, S. (2012). Çocuk yayınları. T. Şimşek. (Ed.), Kuramdan uygulamaya çocuk edebiyatı el kitabı (ss. 71-80) içinde. Ankara: Grafiker Yayınları.

Verhallen, M. J. \& Bus, A. G. (2011). Young second language learners' visual attention to illustrations in storybooks. Journal of Early Childhood Literacy, 11(4), 480-500.

Wagner, L. (2017). Factors influencing parents' preferences and parents' perceptions of child preferences of picturebooks. Frontiers in psychology, 8, 1448.

Wei, C. C., \& Ma, M. Y. (2020). Designing attractive children's picture books: Evaluating the attractiveness factors of various picture book formats. The Design Journal, 23(2), 287-308.

Wiseman, A. (2011). Interactive read alouds: Teachers and students constructing knowledge and literacy together. Early Childhood Education Journal, 38(6), 431-438.

Wolfenbarger, C., \& Sipe, L. (2007). A unique visual and literary art form: Recent research on picturebooks. Language Arts, 84(3), 273-280.

Yaden, D. B., Smolkin, L. B., \& MacGillivray, L. (1993). A psychogenetic perspective on children'sunderstanding about letter associations during alphabet book readings. Journal of Reading Behavior, 25(1),43-68.

Yılar, Ö. ve Celepoğlu, A. (2013). Çocuk yayınları ve bu yayınlarda bulunması gereken temel unsurlar. Yılar, Ö. ve Turan, L. (Ed.), Eğitim fakülteleri için çocuk edebiyatı (ss. 39-61) içinde. Ankara: Pegem.

Yıldız, C., Yazıcı, D. N., \& Durmuşoğlu, M. C. (2016). 2010-2015 yılları arasında yayımlanmış resimli çocuk kitaplarının resimleme özelliklerinin incelenmesi. Uluslararası Erkeen Cocukluk Eğitimi Çalısmalar Dergisi, 1(1), 12-27. 


\section{Resimli Öykü Kitaplarını Değerlendirme Ölçeği}

\begin{tabular}{|c|c|}
\hline \multicolumn{2}{|c|}{ KÜNYE BİLGÍLERİ } \\
\hline Kitabın Ad1 & \\
\hline Yazar1/Çevirmeni & \\
\hline Resimleyeni & \\
\hline Yayınevi & \\
\hline Yayın Y11 & \\
\hline Bask1 Sayıs1 & \\
\hline Sayfa Sayıs1 & \\
\hline
\end{tabular}

\begin{tabular}{|c|c|c|c|c|}
\hline Madde & Açıklamalar & $\begin{array}{l}\text { Yetersiz } \\
\text { (1) }\end{array}$ & $\begin{array}{l}\text { Kismen } \\
\text { Yeterli } \\
\text { (2) }\end{array}$ & $\begin{array}{l}\text { Yeterli } \\
\text { (3) }\end{array}$ \\
\hline Kapak resmi ilgi çekicidir. & $\begin{array}{l}\text { Kitabın kapağında yer alan resimleme } \\
\text { tasarım özellikleri açısından dikkat çekici } \\
\text { özelliklere sahiptir. }\end{array}$ & & & \\
\hline $\begin{array}{l}\text { Kitap sayfalarının yarısından } \\
\text { fazlası resimlerden oluşmaktadır. }\end{array}$ & $\begin{array}{l}\text { Kitabın her sayfasında yer alan } \\
\text { resimlemeler, sayfanın yarısından fazlasinı } \\
\text { oluşturmaktadır. Kitapta genel olarak } \\
\text { resimler yazılardan daha fazla yer } \\
\text { almaktadır. }\end{array}$ & & & \\
\hline $\begin{array}{l}\text { Aynı sayfadaki metinler ve } \\
\text { resimler birbiriyle uyumludur. }\end{array}$ & $\begin{array}{l}\text { Kitabın her sayfasında metinde yer alan } \\
\text { olay/özellik/durum/duygu vb. resimlere } \\
\text { yansıtılarak, doğru bir şekilde çizilmiştir. }\end{array}$ & & & \\
\hline $\begin{array}{l}\text { Resimler estetik değer taşımakta- } \\
\text { dır. }\end{array}$ & $\begin{array}{l}\text { Her sayfadaki resimlemeler detaylı ve özenli } \\
\text { çizimlere sahiptir. Sayfalardaki resimleme- } \\
\text { lerde birbirinin aynısı arka plan ve resimler } \\
\text { yer almamaktadır. }\end{array}$ & & & \\
\hline $\begin{array}{l}\text { Resimler çocuğun gelişim } \\
\text { düzeyine uygundur. }\end{array}$ & $\begin{array}{l}\text { Resimler erken çocukluk dönemindeki } \\
\text { çocuklarına gelişim özelliklerine uygun } \\
\text { olarak somut ve anlaşllırdır. Çocukların } \\
\text { anlayamayacakları derecede soyut çizimlere } \\
\text { yer verilmemiştir. }\end{array}$ & & & \\
\hline $\begin{array}{l}\text { Kitaptaki karakterlerin özellikleri } \\
\text { ve hareketleri (beden dili, duygu- } \\
\text { lar vb.) resimlere doğru } \\
\text { yansitılmıştır. }\end{array}$ & $\begin{array}{l}\text { Öykünün metninde anlatılan du- } \\
\text { rum/özellik/duygu/olaylar kapsamında ka- } \\
\text { rakterlerin özellikleri ve hareketleri resimle- } \\
\text { melerde doğru bir şekilde çizilmiştir. }\end{array}$ & & & \\
\hline $\begin{array}{l}\text { Resimlemede kullanılan renkler } \\
\text { canlı ve dikkat çekicidir. }\end{array}$ & 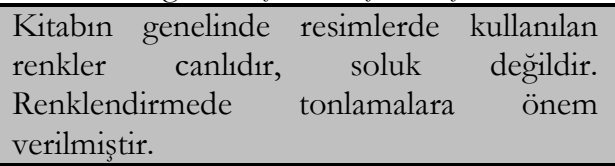 & & & \\
\hline $\begin{array}{l}\text { Öykünün konusu çocuğun yaşına } \\
\text { ve gelişim düzeyine uygundur. }\end{array}$ & $\begin{array}{l}\text { Öyküde ele alınan konu erken çocukluk } \\
\text { dönemindeki çocukların dil gelişimi, bilişsel } \\
\text { gelişim, sosyal-duygusal gelişim özelliklerine } \\
\text { uygundur. }\end{array}$ & & & \\
\hline $\begin{array}{l}\text { Öykünün konusu çocuklar } \\
\text { açisından ilgi çekicidir. }\end{array}$ & $\begin{array}{l}\text { Öykü çocuklar açısından merak uyandırıcı } \\
\text { özelliğe sahiptir. İlginin canlı tutulması için, } \\
\text { olay ve ayrıntılar merak uyandırıcı biçimde } \\
\text { kurgulanmış ve sunulmuştur. }\end{array}$ & & & \\
\hline 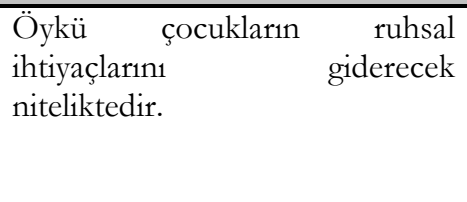 & $\begin{array}{l}\text { Öyküde çocukların güven, sevgi, sevilme, } \\
\text { sevme, öğrenme, bir gruba ait olma, oyun, } \\
\text { değişiklik ve estetiklik gibi ruhsal } \\
\text { ihtiyaçlarından en az birine uygun şekilde } \\
\text { yer verilmiştir. }\end{array}$ & & & \\
\hline
\end{tabular}




\begin{tabular}{|c|c|c|c|c|}
\hline Madde & Açıklamalar & $\begin{array}{l}\text { Yetersiz } \\
\text { (1) }\end{array}$ & $\begin{array}{l}\text { Kusmen } \\
\text { Yeterli } \\
\text { (2) }\end{array}$ & $\begin{array}{c}\text { Yeterli } \\
\text { (3) }\end{array}$ \\
\hline $\begin{array}{l}\text { Öykü çocuğun yaratıc1 hayal } \\
\text { gücünü beslemektedir. }\end{array}$ & $\begin{array}{l}\text { Öykü çocukların farklı düşünme becerilerini } \\
\text { ve hayal güçlerini besleyen olaylar, } \\
\text { karakterler, durumlar vb. içermektedir. }\end{array}$ & & & \\
\hline $\begin{array}{l}\text { Öyküde kullanılan dil açık, } \\
\text { anlaşılır ve dil bilgisi açısından } \\
\text { doğrudur. }\end{array}$ & $\begin{array}{l}\text { Kitapta somut sözcüklere } \\
\text { sözcüklerden daha çok yer verilmektedir. } \\
\text { Yazım ve noktalama kurallarına dikkat } \\
\text { edilmiştir ve yabancı sözcükler yerine } \\
\text { Türkçe sözcükler kullanılmıştır. }\end{array}$ & & & \\
\hline $\begin{array}{l}\text { Öyküde kullanılan dil ve üslup } \\
\text { çocukların yaşına ve gelişim } \\
\text { düzeyine uygundur. }\end{array}$ & $\begin{array}{l}\text { Öyküde, çocukları istenmeyen eğilimlere } \\
\text { sürükleyecek anlatım biçimlerinden } \\
\text { kaçınılmıştır ve argo sözcüklere yer } \\
\text { verilmemiştir. }\end{array}$ & & & \\
\hline $\begin{array}{l}\text { Öykünün üslubu öğüt verici ve } \\
\text { öğretici değildir. }\end{array}$ & $\begin{array}{l}\text { Öykü bir ders ya da ahlaki mesaj verme } \\
\text { kaygısı gütmemekte; anlamı çocukların } \\
\text { kendilerinin çıarmalarına ve yorum } \\
\text { yapmalarına olanak sağlamaktadır. }\end{array}$ & & & \\
\hline $\begin{array}{lrr}\text { Öykü } & \text { çocuğun } & \text { sözcük } \\
\text { dağarcığını } & \text { geliştirecek } \\
\text { niteliktedir. } & \\
\end{array}$ & $\begin{array}{l}\text { Öyküde çocukların yeni öğrenecekleri } \\
\text { sözcüklere, kavramlara ya da terimlere yer } \\
\text { verilmiştir. }\end{array}$ & & & \\
\hline $\begin{array}{l}\text { Öykünün ana fikri/teması açık, } \\
\text { net ve anlaşılırdır. }\end{array}$ & $\begin{array}{l}\text { Öykünün ana fikri çocuğun dünyasıyla } \\
\text { çelişmemektedir ve çocuk açısından akıl } \\
\text { karıştırıcı değildir. }\end{array}$ & & & \\
\hline $\begin{array}{l}\text { Öykünün giriş, gelişme ve sonuç } \\
\text { bölümleri vardır. }\end{array}$ & $\begin{array}{l}\text { Öykü bir giriş bölümü ile başlamakta, } \\
\text { gelişme bölümüyle devam etmekte ve sonuç } \\
\text { bölümü ile bitmektedir. }\end{array}$ & & & \\
\hline $\begin{array}{ll}\text { Öyküde } & \text { yer alan karakterler } \\
\text { çocuğun } & \text { Özdeşim kurması ve } \\
\text { model alması için uygundur. }\end{array}$ & $\begin{array}{l}\text { Öyküdeki karakterlerin çoğunluğu inandırıcı } \\
\text { ve çocuğun model olması açısından } \\
\text { uygundur. }\end{array}$ & & & \\
\hline $\begin{array}{l}\text { Öykü etik ve evrensel değerlere } \\
\text { (sevgi, sayg1, demokrasi vb.) } \\
\text { önem vermektedir. }\end{array}$ & $\begin{array}{l}\text { Öykü sevgi, sayg1, demokrasi vb. etik ve } \\
\text { evrensel değerleri yüceltmekte ve herhangi } \\
\text { bir şiddet unsuru içermemektedir. }\end{array}$ & & & \\
\hline $\begin{array}{l}\text { Öykü dil, din, etnik köken, cinsi- } \\
\text { yet vb. açısından kalıp yargılar } \\
\text { oluşturmamaktadır. }\end{array}$ & $\begin{array}{l}\text { Öykü dil, din, etnik köken, cinsiyet vb. aç1- } \\
\text { sindan eşitlikçi bir yaklaşıma sahip olup öy- } \\
\text { küde yer alan karakterler/olaylar/durumlar } \\
\text { herhangi bir kalıp yargiya yol açmayacak şe- } \\
\text { kilde yer almaktadır. }\end{array}$ & & & \\
\hline $\begin{array}{l}\text { Öykü çocuğa çözebileceği } \\
\text { problemler sunmaktadır. }\end{array}$ & $\begin{array}{l}\text { Öyküde çocukların dil, bilişsel ve sosyal- } \\
\text { duygusal gelişimlerine uygun olarak en az bir } \\
\text { problem durumu yer almaktadır. }\end{array}$ & & & \\
\hline \multicolumn{2}{|c|}{ TOPLAM PUAN } & & & \\
\hline
\end{tabular}

